\title{
Archaeological Investigations at Fort Martin Scott (41GL52) in Gillespie County, Texas
}

Joseph H. Labadie

Follow this and additional works at: https://scholarworks.sfasu.edu/ita

Part of the American Material Culture Commons, Archaeological Anthropology Commons, Environmental Studies Commons, Other American Studies Commons, Other Arts and Humanities Commons, Other History of Art, Architecture, and Archaeology Commons, and the United States History Commons

Tell us how this article helped you.

This Article is brought to you for free and open access by the Center for Regional Heritage Research at SFA ScholarWorks. It has been accepted for inclusion in Index of Texas Archaeology: Open Access Gray Literature from the Lone Star State by an authorized editor of SFA ScholarWorks. For more information, please contact cdsscholarworks@sfasu.edu. 


\section{Archaeological Investigations at Fort Martin Scott (41GL52) in Gillespie County,}

Texas

\section{Creative Commons License}

(c) (1) (8)

This work is licensed under a Creative Commons Attribution-NonCommercial 4.0 International License 


\section{ARCHAEOLOGICAL INVESTIGATIONS AT FORT MARTIN SCOTT (41 GL 52) IN GILLESPIE COUNTY, TEXAS}

Joseph H. Labadie

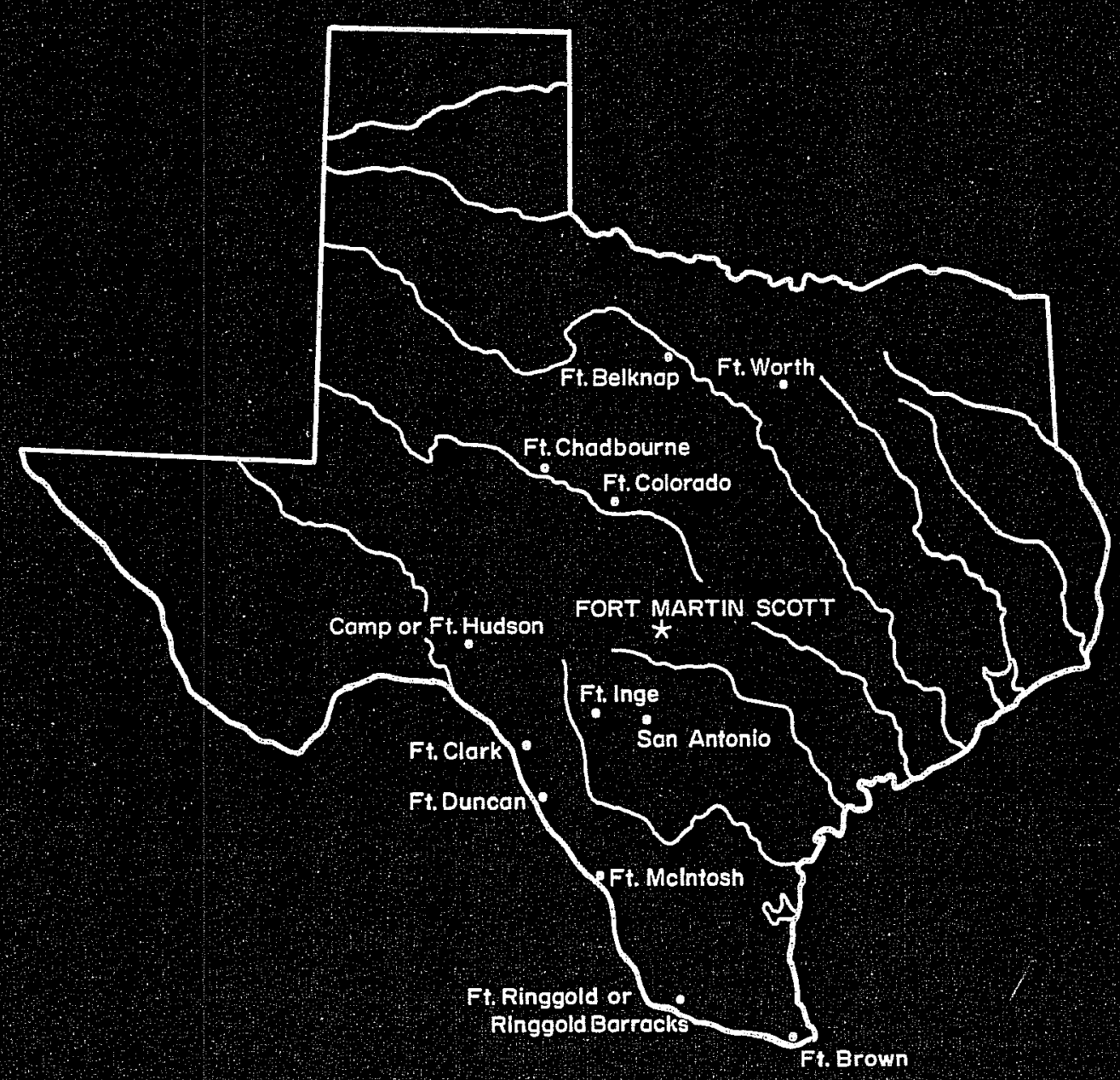

Center for Archaeological Research

The University of Texas at San Antonio

Archaeological Survey Report, No. 169 



\section{ARCHAEOLOGICAL INVESTIGATIONS AT FORT MARTIN SCOTT (41 GL 52) IN GILLESPIE COUNTY, TEXAS}

Joseph H. Labadie

With a contribution by Anne A. Fox

Center for Archaeological Research The University of Texas at San Antonio ${ }^{\circledR}$ Archaeological Survey Report, No. 169 
The following information is provided in accordance with the General Rules of Practice and Procedure, Chapter 41.11 (Investigative Reports), Texas Antiquities Committee:

1. Type of investigation: archaeological testing;

2. Project name: Fort Martin Scott;

3. County: Gillespie;

4. Principal investigator: Thomas R. Hester; co-principal investigators: Jack D. Eaton and Anne A. Fox;

5. Name and location of sponsoring agency: Fredericksburg Heritage Federation, Fredericksburg, Texas;

6. Texas Antiquities Committee Permit No. 555;

7. Published by the Center for Archaeological Research, The University of Texas at San Antonio 78285-0658, 1987.

A list of publications offered by the Center for Archaeological Research can be obtained by sending $\$ 1.00$ to the Center for Archaeological Research, The University of Texas at San Antonio, San Antonio, Texas 78285-0658. 


\section{ABSTRACT}

During May 24-30, 1986, archaeological investigations at Fort Martin Scott (41 GL 52) were conducted by the Center for Archaeological Research at The University of Texas at San Antonio. The fort was established by the U.S. Army in 1848. It was the fifth United States fort in Texas. Only one of the fort's original buildings now exists. The foundations for an additional eight structures were identified and documented by this project. The property on which this old fort is located is owned by the city of Fredericksburg. The Fredericksburg Heritage Federation plans to develop the area as a day-use facility which includes archaeological and historical interpretations of the fort during its tenure (1848-1853) as a military outpost on the western frontier. 


\section{TABLE OF CONTENTS}

ABSTRACT
LIST OF FIGURES
LIST OF TABLES
ACKNOWLEDGMENTS 


\section{LIST OF FIGURES}

1. Location of Gillespie County and Fort Martin Scott (41 GL 52) . . . 2

2. Photostatic Copy of the 1853 Inspection Sketch Map of

Fort Martin Scott . . . . . . . . . . . . . . . . . . 8

3. Existing Structures at Fort Martin Scott ............. 11

4. Site Plan Map of Fort Martin Scott (41 GL 52) . . . . . . . . . . 12

5. Foundation Remnants for Structures $A$ and $B$............. 18

6. Floor Plan Drawing of Structures A and B . . . . . . . . . . . 19

7. Foundation Remnants for Structure E . . . . . . . . . . . . . 22

8. Floor Plan Drawing of Structures E and G............ 23

9. Foundation Remnants for Structures $G$ and $J$........... 25

10. Floor Plan Drawing of Foundation Remains for Structure J . . . . . 27

11. Foundation Remnants for Bake Oven and Structure 0 ........ . 28

12. Floor Plan Drawing of Structure 0 . . . . . . . . . . . 30

13. Square-Cut Nails Recovered from Survey Area 1. . . . . . . . . 31

14. Artifact Scatter in Survey Area 1 . . . . . . . . . . . . . . 32

15. Ceramic Artifacts Recovered at Fort Martin Scott . . . . . . . . . 37

16. Artifacts Recovered at Fort Martin Scott . . . . . . . . . . . . 39

\section{LIST OF TABLES}

1. List of Archaeological and Historical Investigations Conducted at 19th-Century Military Forts in Texas . . . . . . . . . . . . 4

2. Post Commanders at Fort Martin Scott . . . . . . . . . . . . . 7

3. Provenience for Artifacts Recovered at Fort Martin Scott . . . . . 20

4. Listing of Structures and Structural Localities Investigated by this Project................. . . 41 


\section{ACKNOWLEDGMENTS}

The Fort Martin Scott project involved a number of people who are deserving of special thanks for their individual contribution to this project's overal1 success. They include the project staff: Kenny Wright, Paul Maslyk, Kelly Scott; volunteers Rochelle Leneave, Ann Stone, Cathy Dodt-Ellis, and Alice Thomas. Thanks also to UTSA staff member Waynne Cox for his research assistance. Anne A. Fox served as the overall project director for the CARUTSA.

This project was aided immeasurably by Joe Bolin of the Fredericksburg Heritage Federation, who made the arrangements for camping facilities and the other necessary social amenities. Other Federation members and local residents who were involved in this project included Dwight Aystrack, Ty Cox, Barry Wagner, Sam Morin, Tracey Mertz, Russe11 Thomas, Ruby Rowe, and Ward Woodrick. Special thanks to Malcom Johnson for his work with the metal detector, to Don Braeutigam who provided us with much of the Braeutigam family history which has been used in this report, and to Sam Nesmith for his analysis of the military artifacts recovered at the site. 


\section{INTRODUCTION}

Fort Martin Scott is located ca. 2.4 miles east of Fredericksburg, just east of U.S. Highway 290 in Gillespie County, Texas (Fig. 1). The site (41 GL 52) is on the National Register of Historic Places. The fort was established in 1848 as the fifth United States fort in Texas. The site is owned by the City of Fredericksburg and consists of ca. 11 acres of 1 and which has been leased by the City to the Fredericksburg Heritage Federation. The Heritage Federation plans to develop Fort Martin Scott as a day-use recreational facility. Historical interpretations and partial reconstruction of some of the original structures figure prominently in the current redevelopment plan.

During May 24-30, 1986, archaeological investigations at Fort Martin Scott were conducted by the Center for Archaeological Research of The University of Texas at San Antonio (CAR-UTSA). This project was carried out under contract with the Fredericksburg Heritage Federation (1etter dated May 14, 1986) by the CAR-UTSA, under the specific terms of Texas Antiquities Committee Permit No. 555 .

The project was conducted under the general supervision of Thomas R. Hester (principal investigator) and Jack D. Eaton, Center director and associate director, respectively. Anne A. Fox was the project director and coprincipal investigator; she also is the author of the section Recommendations for Further Work. Joseph Labadie was the project field director and author of this report. The primary goals of this project were: (1) to locate and map as many buildings of the original fort as possible in the time allotted and assess the artifactual remains present, using small archaeological tests; (2) to establish a permanent site datum; and (3) to obtain and review historic documents, military maps, and documents prepared by Wagner and Klein, Inc. Following the field work, recovered artifacts were cleaned, catalogued, and analyzed; they are currently curated at the CAR-UTSA. A11 field notes, photographs, and drawings pertaining to the field work and laboratory analysis are on file at the CAR-UTSA.

\section{SITE SETTING}

The site of Fort Martin Scott is located on the right (west) bank of Barons Creek which is a tributary of the Pedernales River. The fort is situated on both the upper and lower terraces of the modern floodplain of the creek. There is a 25-foot difference in ground surface elevation across the site which gradualiy slopes from west to east.

The entire area leased by the City to the Fredericksburg Heritage Federation consists of Quaternary deposits comprised of Pleistocene (upper) terrace and Holocene (lower) terrace deposits (Prewitt 1979). The upper terrace was formed during the Pleistocene from overbank flooding of Barons Creek which occurred in excess of 14,000 years ago. The soil on this terrace consists of a red sandy clay matrix which contains calcium precipitates. In the vicinity of the former commanders' residence, the upper 10 inches of soil matrix consists of red sandy clay. At ca. 11 inches below the modern ground surface, the matrix is composed almost entirely of red clay which contains numerous calcium carbonate and hematite (iron) concretions. This upper 


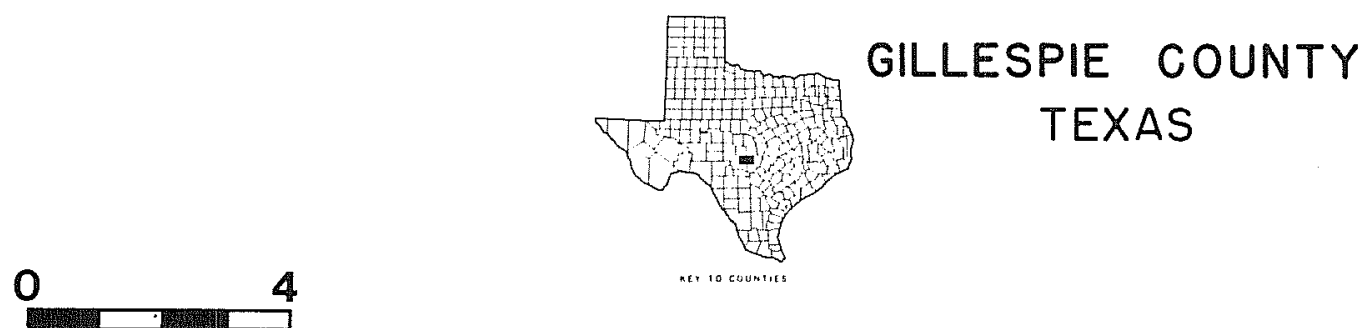

miles

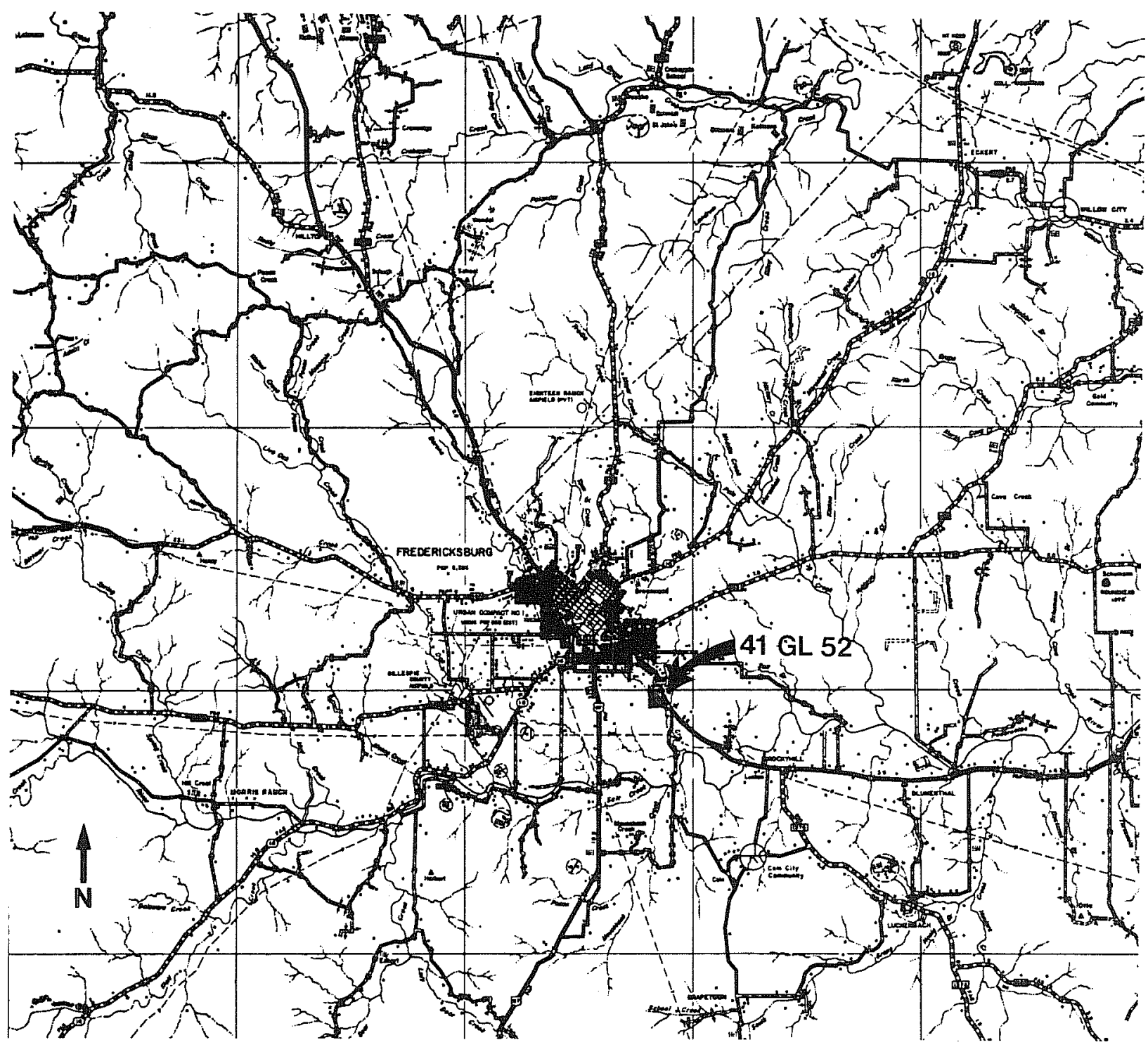

Figure 1. Location of Gillespie County and Fort Martin Scott (41 GL 52). 
terrace is most pronounced in the westernmost portions of the site and dips noticeably to the southeast to the lower Holocene terrace.

The Holocene terrace, on which the guardhouse and the Braeutigam Homestead are situated, was produced by overbank flooding which has occurred in this portion of Barons Creek since the end of the Ice Age. The soil consists of a brownish sandy clay loam with stratified lenses of gravel exposed in both cutbanks of the creek.

Underlying both of these terraces are outcrops of Edwards Limestone of the Mesozoic era Cretaceous system (Prewitt 1979). These outcroppings are most noticeable on the east side of Barons Creek ca. 1/4 mile north of the site area. On the west side of the creek, there is an outcropping just north of the city property line which has been exposed by the north-to-south flow of water in Barons Creek. Similar outcroppings, or perhaps these, were used as the quarry sources for stone to construct the buildings at the fort.

Vegetation at the site consists mainly of short grasses, herbaceous plants, and perennial forbs. Much of the site area is used for the pasturage of cattle. There are several large live oak and mesquite trees, some of which are large enough to suggest they may have been standing when the fort was in operation (1847-1853). Observed fauna consists of raccoon, skunk, owls, and a variety of snakes, frogs, and turtles near Barons Creek.

\section{PREVIOUS RESEARCH}

The CAR-UTSA investigations at Fort Martin Scott represent the first archaeological testing at Fort Martin Scott. Wagner and K1ein, Inc. (1983) previously had prepared a preservation plan for the Fort Martin Scott property and buildings. Their report contains numerous scaled drawings, photographs, and photostatic copies of original documents obtained through the National Archives in Washington, D.C. Also included is a copy of the National Register of Historic Places Nomination Form for Fort Martin Scott (Prewitt 1979) which contains a brief historical overview of Fort Martin Scott. Wagner and Klein, Inc. (1983:30) stressed that the governing principles of their recommended preservation project were that, prior to any development, archaeological investigation should be conducted and that all restoration and stabilization efforts should utilize original materials and construction techniques. Such governing principles have been very effectively implemented at other Texas forts and outposts. The reader is referred to Table 1 for a list of specific fort sites where archaeological and historical investigations have been conducted.

\section{HISTORICAL BACKGROUND}

Fredericksburg has a number of historic buildings and homes which reflect the city's pioneer history during the mid-to-1ate 19th century. Fort Martin Scott played a vital role in the earliest years of the settlement, acting primarily for the protection of the colony. Currently available records indicate that no major hostilities ever took place at this frontier outpost. 
TABLE 1. LIST OF ARCHAEOLOGICAL AND HISTORICAL INVESTIGATIONS CONDUCTED AT 19TH-CENTURY MILITARY FORTS IN TEXAS

Location

Fort Concho

Fort Ewell

Fort Griffin

Fort Inge

Fort Lancaster

Fort Leaton

Fort McIntosh

Fort McKavett

Fort Richardson

Fort Martin Scott
Be11, Klein, and Hoffman (1980)

McGuire (ms.)

Clarke (1935), Maxwel1 (1940), Rister (1956), Graham (1968), 01ds (1969), A. Fox (1973, 1975, 1976), Yates (1975)

Ne1son $(1981,1982)$

Fletcher (1932), Brown (1965), Hays and Jelks (1966), Taniguchi, Graham, and Hamblett (1968b), Clark (1972)

Ing and Kegley (1971)

Medl in (1977a, 1977b), Ivey, Med7in, and Eaton (1977), D. Fox (1978a, 1978b, 1979)

Crimmins (1939, 1947a, 1947b, 1948), Rickey and Pope (1966), Taniguchi, Graham, and Hamblett (1968a), Green (1969), Carter (1974), B7ack and Ing (1980)

$01 \operatorname{sen}(1975)$

Prewitt (1979), Wagner and Klein, Inc. (1983), Fredricksburg Chamber of Commerce (n.d.) 
The history of Fort Martin Scott as an active U.S. Army fort was short 1ived, lasting just five years. However, the real legacy of Fort Mart in Scott involves the economic stability that it brought to Fredericksburg and Gi1lespie County.

The story of Fort Martin Scott is one that is still waiting to be told. A tremendous amount of information currently exists about the fort, some of its soldiers, and the Indians who traded at the fort. Unfortunately, a thorough archival and historical search has yet to be initiated that would attempt to assemble such documents in a single, concise volume. Such a task is beyond the scope of this project, and only a brief overview of the historical events associated with the fort will be presented in this report.

In 1842 , a group of 20 German noblemen met at a castle belonging to the Archduke of Nassau on the Rhine River and formed the Verein, or society, also known as Adelsverein or Association of Noblemen (King 1967:32-38). The Adelsverein had as its purpose the acquisition of 1 and in Texas on which to settle German immigrants. In 1844, the Adelsverein was reorganized as a stock company and renamed the Society for the Protection of German Immigrants in Texas (ibid.). The society acquired the needed 1 and and, although facing severe fiscal problems, landed the first group of settlers at Galveston in November and December 1844. On March 21, 1845, they arrived at the infant colony of Braunfels (now New Braunfels; Biesele 1930:119).

In April 1846, 120 persons left New Braunfels in 20 wagons and Mexican twowheeled oxcarts to lay out a new wagon road and survey new lands to the northwest. After 16 days journey, they arrived at the future site of Fredericksburg (Penniger 1971:28-29). By the winter of 1846, the new colony of Fredericksburg was visited and described by $\mathrm{Dr}$. Ferdinand Roemer who noted:

The city lies southeast by northwest which is also the direction of the principal street about two miles in length. The main street, however, did not consist of a continious row of houses, but of about fifty houses and huts, spaced long distances apart on both sides of the street. Most of the houses were $\log$ houses for which the straight trunks of the oak trees growing round about furnished excellent building material.

Most of the settlers, however, were not in the possession of such homes, since they required so much labor, but they lived in huts, consisting of poles rammed into the ground. The crevices between the poles were filled with clay and moss, while the roof was covered with dry grass some even lived in linen tents which proved inadequate during these winter months (Mueller 1935:228-229).

Indian and settler relations at this time had been amicable due principally to negotiated treaties with the Penateka Comanches. John 0. Meusebach, the Commissioner General of Adelsverein, successfully negotiated with the Comanche Indian chiefs, Buffalo Hump, Santana, and 01d Ow7 (Prewitt 1979). ShortTy afterward, Fort Martin Scott was established to reinforce the treaty; it is significant that this was one of the first U.S. military forts established in Texas for the specific purpose of enforcing such treaties 
(ibid.). A brisk trade soon developed between the two groups with the Indians selling venison, bear meat, and bear grease to the settlers. Stored in deerskins from which the hair had been scraped, with the leg and neck openings closed, a gallon of bear grease sold for a dollar or its equivalent in goods and was used in cooking, for oil lamps, and in other ways (Newcomb 1961:48). Bears were then so plentiful in the Fredericksburg vicinity that "each Indian often had 60 gallons of such fat for sale" (Mueller 1935:232).

In the fall of 1847, the Mormon colony at Zodiac was established several miles southeast of Fredericksburg along the Pedernales River. Using the river's waters, they constructed a sawmi11, grist mi11, and turning lathe and were soon supplying Fredericksburg with ground corn, lumber, furniture, and their general know-how in carpentry and agriculture (Newcomb 1961:52). Political differences with their German neighbors, and a flood in 1850 that destroyed their mill, led them to abandon their settlement (ibid.). This sawmill may very well have provided the timber necessary for the initial construction of Fort Martin Scott. Appendix I provides the reader with a typewritten transcription of a list for materials and lumber necessary for the construction/completion of several of the post's structures in 1850-1851.

Following Texas' statehood (1845) and the signing of the Treaty of Guadalupe Hidalgo in February 1848, which concluded the Mexican War, a period of rapid growth and economic expansion began throughout Texas. The western frontier was rapidly expanding, and in the spring of 1848, the Texas Legislature asked Congress to assist in the protection of settlers from the Indians (Newcomb 1961:60). As a resu7t, Congress appropriated monies to construct a series of posts and forts which were built and garrisoned (Appendix II). In the threeyear period from 1847 to 1850, the state's non-Indian population increased by almost $50 \%$ to 212,592 persons (ibid.:61). A census from 1850 shows a population of 12 soldiers residing at the fort in that year (Appendix III). Prewitt (1979) notes that the U.S. Federal Census of 1850 listed 100 officers and enlisted men, four officers' wives, and seven children at the fort.

Camp Houston was established two miles southeast of Fredericksburg on the old San Antonio-Fredericksburg highway in 1848 (Eastman 1961:xvii). Captain Seth Eastman, in command of Companies $D$ and $H$ of the 1 st Infantry, arrived in Fredericksburg on December 5, 1848, and remained unti1 March 10, 1849 (ibid.). The camp was referred to as Camp Houston or the Camp near Fredericksburg unti1 1849. It was then renamed Fort Martin Scott in honor of Major Martin Seott (5th U.S. Infantry) who was killed September 8, 1847, at the battle of Molino del Rey, Mexico (National Archives 1849). The post commanders that succeeded Captain Eastman are presented in Table 2.

In 1853, the northern chain of military posts and forts was visited by U.S. Army inspectors (see Crimmins 1947a, 1947b, 1948, 1949). During August 1315,1853 , the facilities and troops at Fort Martin Scott were inspected by $W$. G. Freeman (Crimmins 1949). The inspection report (see Appendix IV) documented the number and types of structures at the fort and discussed the provisions and conditions of the quartermasters, subsistence, and medical departments. Of considerable importance, attached to the 1853 inspector's report was a "Rough Plan of Fort Martin Scott" (Wagner and Klein, Inc. 1983:15) that also contained brief descriptions and measurements of structures depicted in the sketch map (see Fig. 2). The complete text of the report is presented in Appendix IV. 
TABLE 2. POST COMMANDERS AT FORT MARTIN SCOTT

\begin{tabular}{lllll}
\hline \multicolumn{1}{c}{ Name } & \multicolumn{1}{c}{ Rank } & Company & Regiment & Assumed Command \\
\hline Wi17iam R. Montgomery & Bvt. Lt. Col. & I & 8th Infantry & Apri1 11, 1849 \\
Collison R. Gaten & Bvt. Major & K & 8th Infantry & May 30, 1849 \\
Edward D. Blake & 2nd Lieut. & K & 8th Infantry & June 28, 1849 \\
Wi17iam Steele & Bvt. Capt. & F & 2d Dragoons & July 16, 1849 \\
Thomas T. Fountleroy & Lt. Col. & - & 2d Dragoons & Aug. 23, 1849 \\
Wi11iam Steele & Bvt. Capt. & F & 2d Dragoons & Sept. 11, 1849 \\
John Boardaley & Capt. & K & 8th Infantry & Oct. 11, 1849 \\
Thomas Staniford & Bvt. Col. & - & 8th Infantry & Dec. 22, 1849 \\
Theodore Fink & 2d Lt. & C & 8th Infantry & Oct. 1, 1852 \\
James Longstreet & Bvt. Major & C & 8th Infantry & Feb. 2, 1853 \\
Theodore Fink & 2d L.t. & C & 8th Infantry & March 12, 1853 \\
Eugene B. Beaumont & Bvt. Lt. Col. & A & 4th Cavalry & Oct. 18, 1853 \\
& & & & \\
& & & & \\
\hline \hline
\end{tabular}

The report also stated:

There seems to me little advantage in continuing to occupy Fort Martin Scott, and I think the discipline of the same would be promoted by sending the detachment to its regiment. Forage for passing trains might be purchased from dealers in Fredericksburg, at rates fixed by the Quartermasters' Department, as is now done in Castroville, and the necessity of detaching men more than 100 miles from their companies as a guard and a small forage depot, would then be obviated.

The inspection report was filed with and accepted by the 8th Military Department in the fall of 1853. On December 29, 1853, the closure of Fort Martin Scott was ordered (National Archives 1853).

The federal government apparently never had title to the land during the tenure of Fort Martin Scott (1847-1853). The 1853 Freeman Inspection Report noted:

The site belongs to Mr. Twohig of San Antonio. It is believed no rent is paid for the 1 and, but the owner has received a considerable sum for fuel and timber cut and the improvements will belong to him when the troops are withdrawn.

Anson Jones, President of the Republic of Texas, on December 4, 1845, issued a letter patent of 640 acres (Survey No. 36) to Nathaniel Townsend, assignee of William 0. Merriwether, located in Bexar County (from which Gillespie County was eventually formed). Townsend also obtained letter patents to seven other surveys in Bexar County, four of which were north of the Pedernales River in the vicinity of present-day Fredericksburg. 


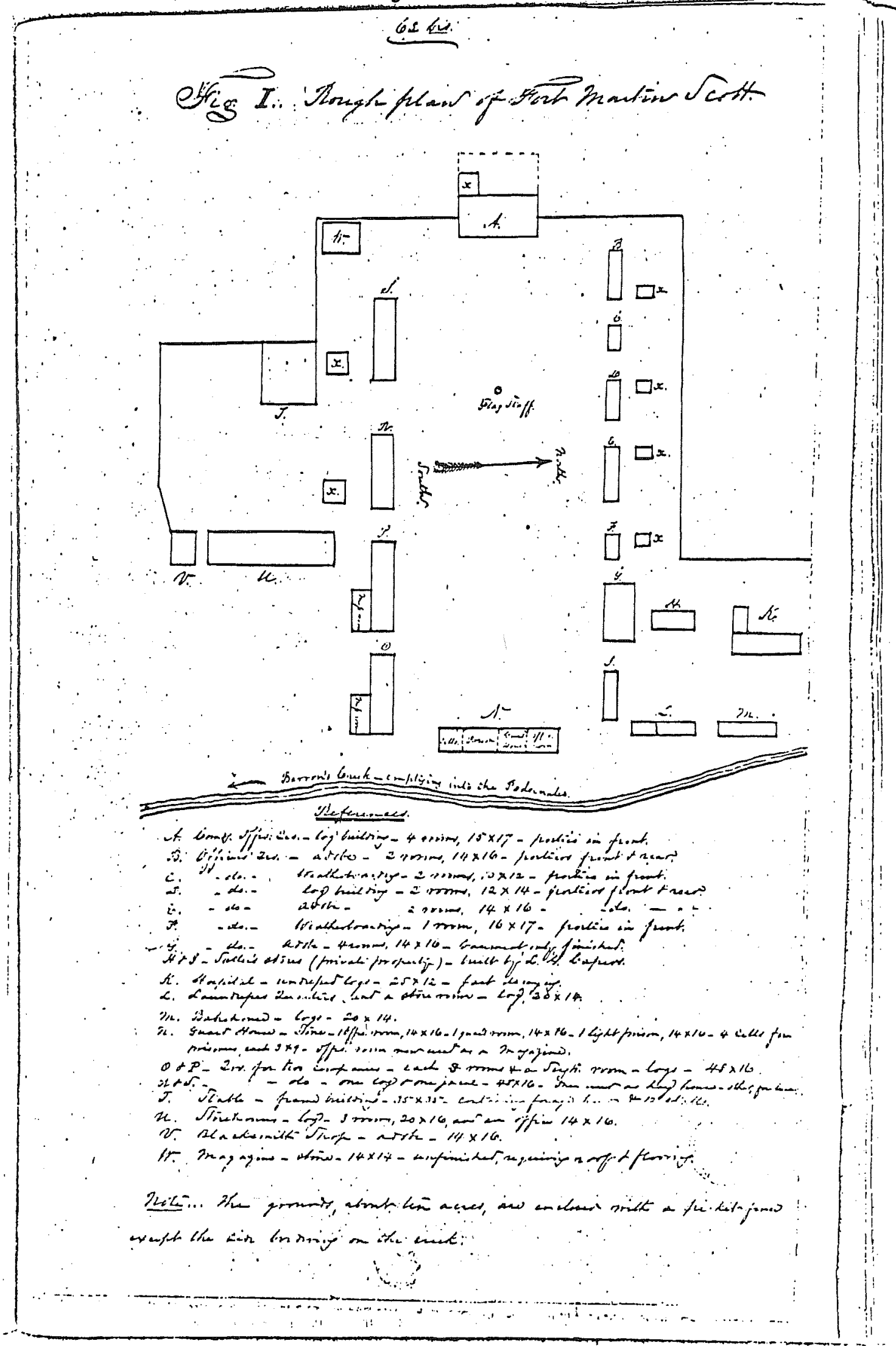

Figure 2. Photostatic Copy of the 1853 Inspection Sketch Map of Fort Martin Scott. Taken from Freeman (1853). 
On February 2, 1852, Townsend sold his 640-acre tract (Survey No. 36) to John Twohig, who was a wealthy businessman residing in San Antonio. In December 1853, Twohig leased a portion of this 640-acre tract to C. C. Frischmeyer (Gillespie County Deed Records Vol. E:211). The lease agreement stated that the lease was a one-year agreement for:

Martin Scott, two houses and lots, which I will point out to him at Fort
same, as also the kitchens and stables on said lots. And that
said Frischmeyer shal1. . and further agrees and binds himself
to preserve and protect buildings, doors, windows, rail and
picked fences, stables, etc., etc., in and about the premises
known as Fort Martin Scott (ibid.).

The Twohig-Frischmeyer lease agreement is interesting in that it pertains to two houses on two separate lots. There is no real mention of the additional structures at Fort Martin Scott. Six months earlier, the inspection by Freeman (August 13-15, 1853) noted 21 existing structures at the fort. On February 9, 1852, Twohig sold an undivided one-half interest in the 640-acre tract to J. J. Wright, who was a doctor in the U.S. Army (Wagner and K1ein, Inc. 1983:16). On June 2, 1852, Wright gave Twohig the power-of-attorney to handle for him a11 matters concerning this and other 1 ands he owned (Penniger $1971: 80)$.

John W. Braeutigam (1829-1884) purchased the 640-acre tract, which included Fort Martin Scott, from Twohig on March 5, 1870, for the sum of $\$ 1600$ in gold coin (Penniger 1971:180). Penniger (1971:188) reported that the fort was held by the Confederates from 1861 to 1865 and that the fort was occupied on an intermittent basis by various U.S. military units and Texas Rangers until 1861 and then by Confederate and Ranger units until 1866 (Wagner and K1ein, Inc. 1983:i). No documentation currently exists for the 27-year period (1853-1870) between the inspection and the later acquisition by Braeutigam. Future research must address this 27-year gap in our knowledge about the history of Fort Martin Scott. From 1879 until 1959, this property remained in the hands of several generations of the Braeutigam family.

The Braeutigam family history (Sauer n.d.) indicates that at the time of the acquisition of the fort property (1870), few of the structures noted in 1853 were still standing. According to Sauer (n.d.), Anna E. Braeutigam, at age 12, helped her father and a number of workmen, both stone masons and carpenters, renovate the old remains of "any consequences left standing, "into a new and permanent home for the Braeutigam family. Anna reportedly cooked meals over an outdoor fireplace for the workmen. John Keller, an old drifter named Johanssen, and a former soldier identified (Sauer n.d.) only as "the soldier who left his blue overcoat behind," may be some of the workers who assisted John W. Braeutigam in his renovation efforts.

Richard V. Braeutigam (1859-1924), one of 11 children of John W. (1829-1884) and Christine K. (1831-1924) Braeutigam, is said to have spent his "teen years" assisting his father in the transformation of the old fort into the family home, and in establishing "his fathers' store, saloon, race track and dance ha11, a 71 of which became known as "Braeutigam's Garten [Garden]" 
(Sauer n.d.). The race track was on the east side of Barons Creek, in a flat field (ibid.).

Braeutigam's Garden was the scene of numerous festivities and celebrations. The first Gillespie County Fair was held on the old fort property in 1881. At the fairs, the feature entertainment besides the exhibits was horse racing. On September 3, 1884, this tranquil scene of a family owned/operated business was shattered by the murder of John W. Braeutigam. Sauer (n.d.) reports that four men came into his store and demanded money; Braeutigam refused, and he was shot dead. Another version (Penniger 1971:187) of this event states that four men entered the saloon and ordered drinks. While being served by Braeutigam, one of the four drew his revolver and demanded the money chest. Instead, Braeutigam reached for his musket that stood in the corner, only to be fatally shot by the robber (ibid.). The Braeutigam family history (Sauer n.d.) makes no mention of the ultimate fate of the four men who perpetrated the murder. Penniger (1971:187), on the four murderers, states:

- . one of them was shot by a Ranger in the lower country when he resisted arrest. Another was delivered to the local jail and met with death when the jail was destroyed by fire. A few years later the third one was shot to death above Mason, and the fourth one presumably the one who committed the murder, a fellow named Fannin escaped.

Following the murder of John $W$. Braeutigam in 1884, the saloon doors were never reopened (Sauer n.d.). Different families bought the rights to the concessions at the Fourth of July celebrations and the annual fair (ibid.). Each child received 42 acres from their father's estate, and the widow of John Braeutigam remained at the old fort property until her death in 1924 at the age of 93. The daughters would in time marry, selling their acreage to their brothers (Sauer n.d.).

Henry W. Braeutigam (1874-1946), age 10 at the time of his father's murder in 1884, became owner of that part of the estate which included the business (Sauer n.d.). He tore down the old dance hall, using the lumber to erect a large and spacious barn (Fig. 3,c) to the north of the family residence, the former guardhouse at the fort. One of the large doors in this barn, which is still in good repair, is "off the huge fort stables, and has two iron hinges which are almost three feet long" (Sauer n.d.).

The Braeutigam family occupied the former site of Fort Martin Scott for 90 years. The old guardhouse (Fig. 3,a,b; Fig. 4, Structure N) served this family as their homestead beginning in 1870, and was continuously occupied until ca. 1955. This property was sold to the city of Fredericksburg in 1959. Changes in the original configuration of this structure are reported by Sauer (n.d.) to have been made by John W. Braeutigam (1829-1884), by Henry W. Braeutigam (1874-1946), and by Raymond Braeutigam (1913- ).

In 1853, the guardhouse is described as consisting of four rooms; from northto-south, an officer's room, guardhouse, and two prison cells. Following the Braeutigam acquisition of the fort (1870), Sauer (n.d.; also Fredericksburg Standard 1955) reports that the guardhouse consisted of three rooms: 


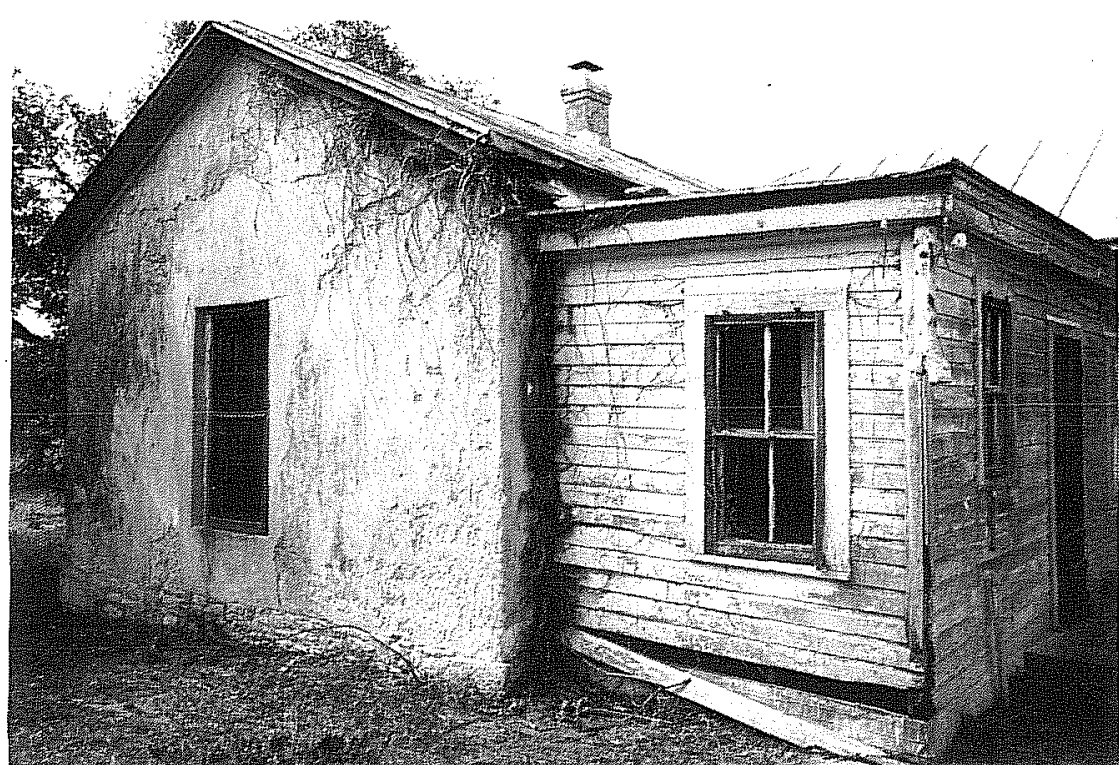

a

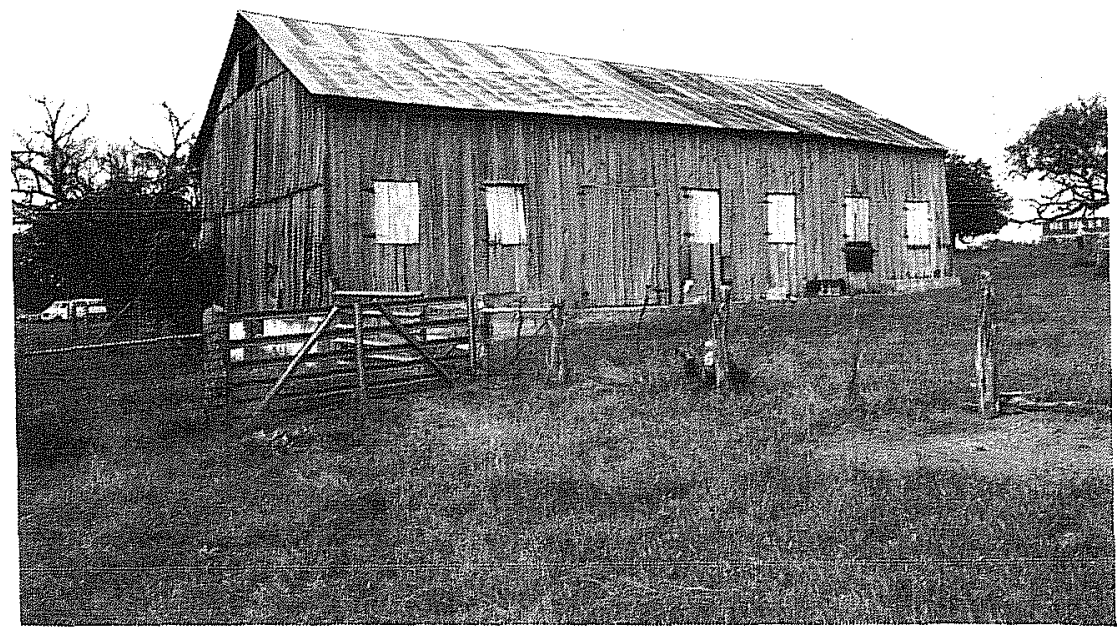

c

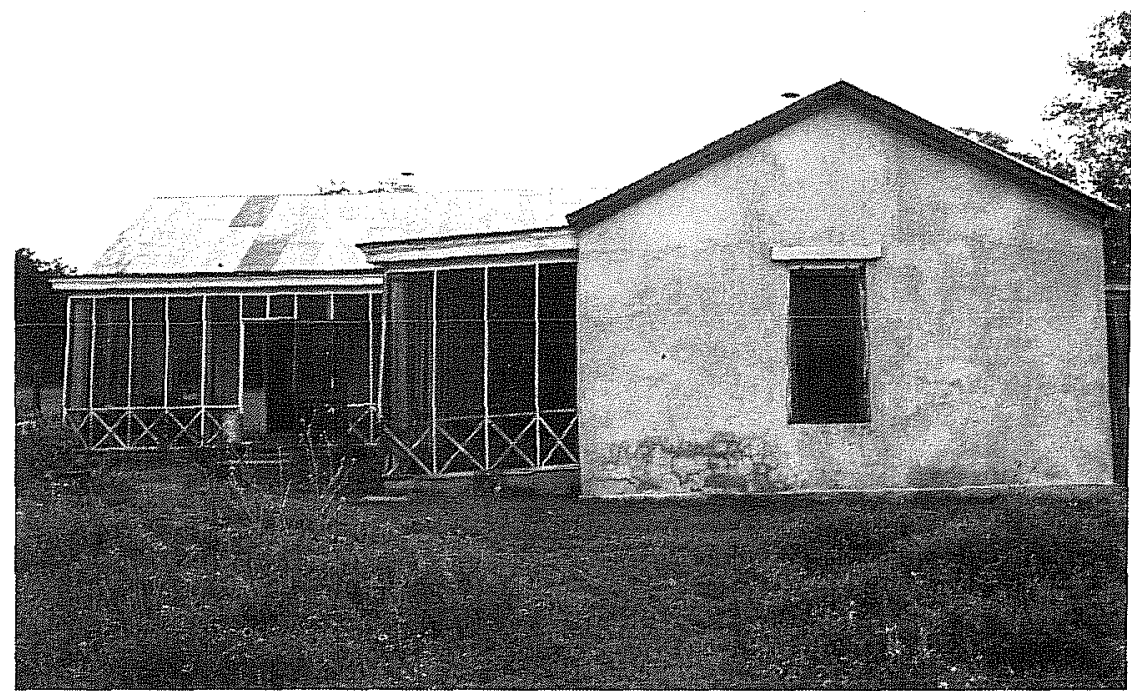

b

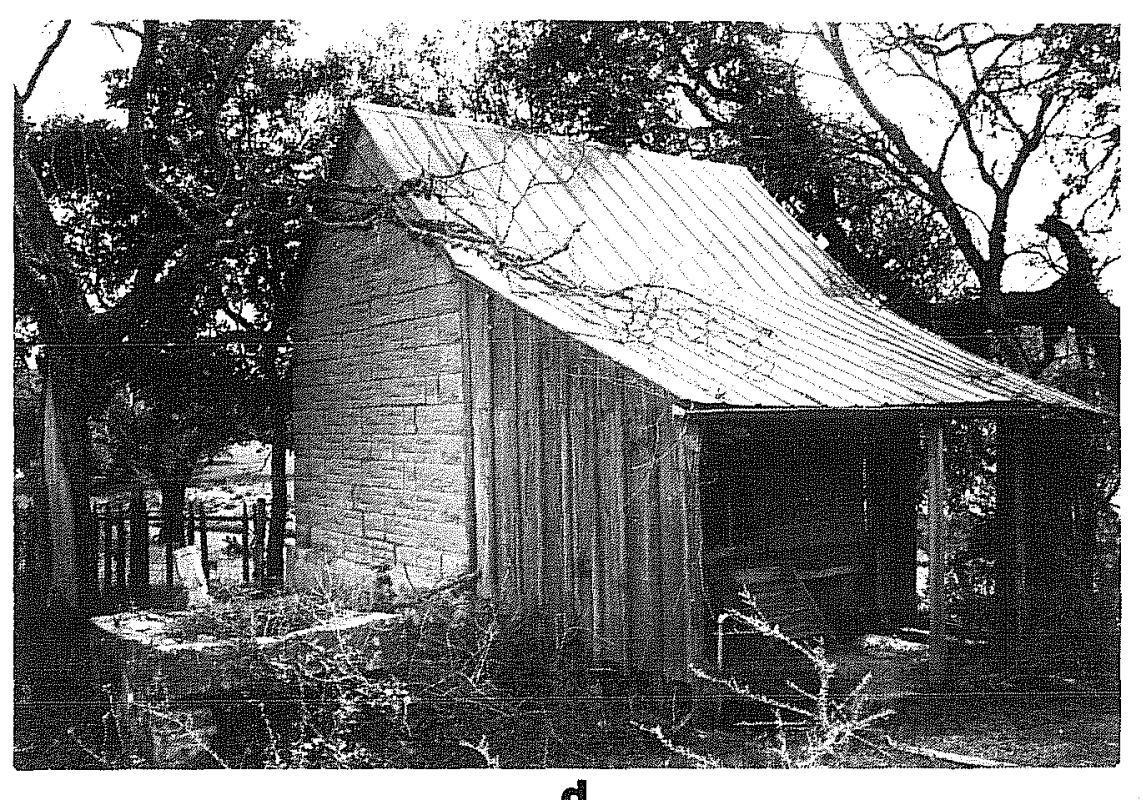

d

Figure 3. Existing Structures at Fort Martin Scott. a, Braeutigam Homestead, north view; b, south view; c, barn; d, outbuilding. 


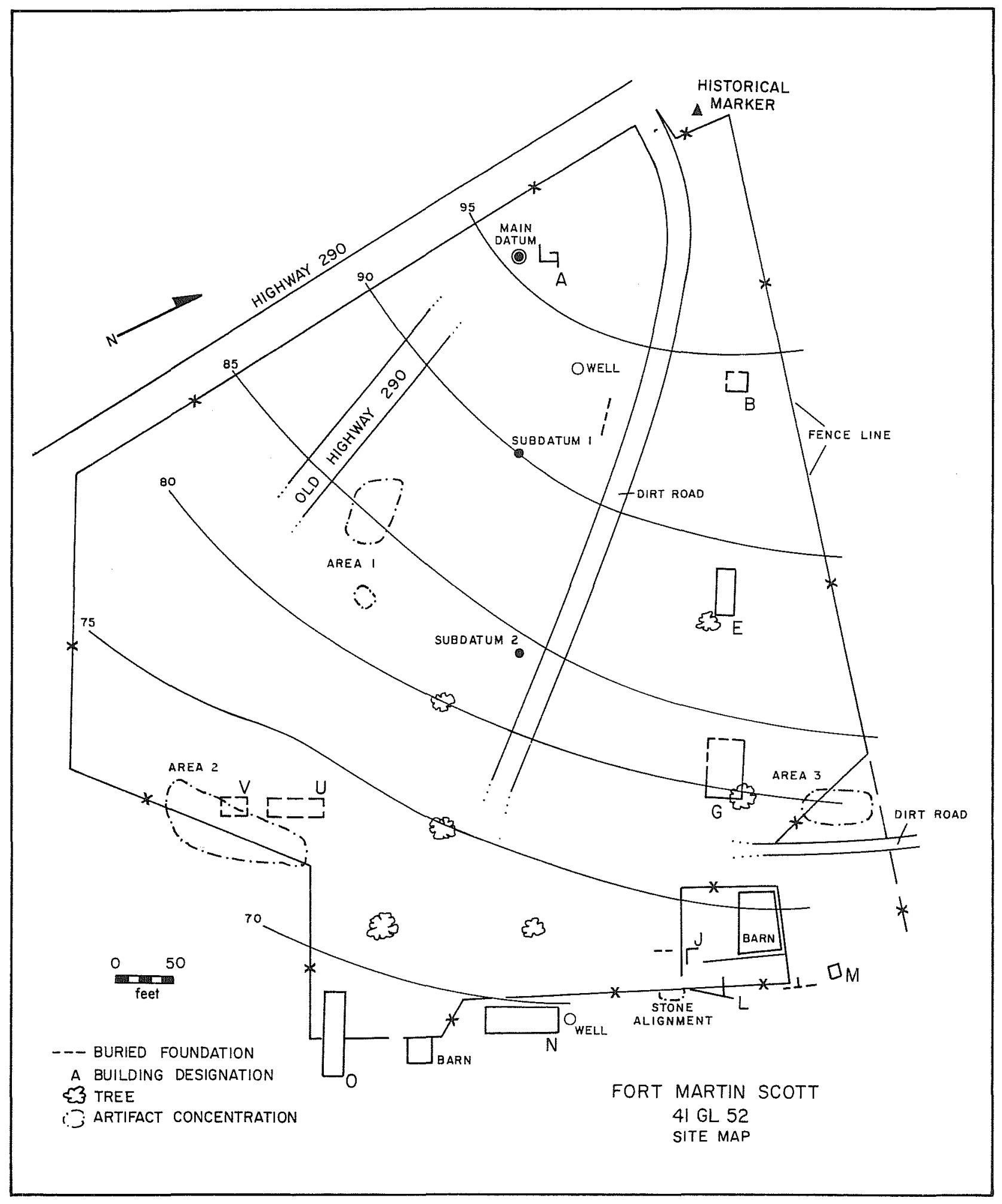

Figure 4. Site Plan Map of Fort Martin Scott (41 GL 52). 
one large jail-room and two smaller officers rooms.. . the jail is the portion at the south end, and was divided by a wood partition to provide a large bedroom for Mrs. Braeutigam, while the inner half of the room became a hall and bedroom. There is a small opening in the ceiling of this hall through which the "borden" or attic space can be viewed. It is remarkable to note heavy beams used for cross pieces which reveal the crude axe marks; and some of the boards upon which the original shingles were najled are 14 inches broad. Next to these rooms [the middle room of the three] was [in 1955] the room of Mr. and Mrs. Raymond Braeutigam and was the largest of the three original rooms, and was the original front entrance. The third room, at the north end was also a bedroom. A11 rooms have large doors-they are the original doors put up when the fort was built.

There is a door between the two bedrooms now [middle and southernmost room?] but in the days of the fort there was a huge double fireplace in this wall, with an open hearth facing into each room. The flue was over four feet across and extended four feet above the roof, however, the fireplace smoked so badly that it was removed [by John W. Braeutigam], making way for the door.

Henry W. Braeutigam (1874-1946) returned to the family homestead shortly after his father's murder in 1884. Sauer (n.d.) reports that he was responsible for the three-room frame construction addition to the existing stone homestead:

The kitchen adjoins the bedroom at the north end of the building [Fig. 3,a]. Next to it is the large dining room which opens onto a comfortable screened porch [of Victorian post and bracket construction]. To the west of this, forming an "L" is the large 1 iving room area which also opens onto the porch that runs along the south side of these two rooms [Fig. $3, \mathrm{~b}]$.

A third set of modifications to the original guardhouse appears to have been made by Raymond Braeutigam (1913-): the addition of the tin roof, rain gutters, and indoor plumbing, including a bathroom. A small building with a cellar and a large outdoor fireplace with an iron kettle (Fig. 3,d) are located just north of the old guardhouse. A second structure (pump house?) adjacent to a rock-lined well is also nearby. The construction of both occurred during the 20th century. The exact date of construction is not known.

There are two wells on the property now owned by the City of Fredericksburg. Both are lined with rock and very similar in construction. Neither well is depicted on the 1853 inspection map, and, they are therefore assumed to be post-1870 additions to the property. One well is located on the hill not far from the Commander's House and in the vicinity of where "Braeutigam's Garten" (saloon and store) once stood. Don. Braeutigam thinks that this well, and the other well near the former guardhouse, date to the period when the site was occupied as a fort (Don Braeutigam, personal communication, May 30, 1986). 
The specific issue of when the wells were added should be addressed in future research.

Future archaeological investigations at Fort Martin Scott should proceed concurrently with additional archival and historical research. Several specific issues have been pointed out in this section of the report. Additional recommendations are in a section authored by Anne Fox later in this report.

\section{FIELD METHODS}

Research and field methods employed during this project followed the Council of Texas Archeologists' (CTA 1981) performance guidelines and consisted of standard field recording procedures (Hester, Heizer, and Graham 1975). A11 extant building foundations were mapped by plane table and alidade (Fig. 4). All systems of field referencing utilized feet and inches rather than the standard metric system.

The main horizontal system of referencing consisted of a 640-foot east-west base line which extended from the guardhouse (Structure $N$ ) to the foundation remnants associated with the former Commanders' House (Structure A; Fig. 4). A main site datum was established near Structure A (1627 feet above Mean Sea Level [MSL]) which also served as the datum for vertical referencing for the entire site. Mapping stations were placed at 100-foot intervals along the primary east-west base 1ine. Structural foundations associated with known historical buildings received an additional temporary datum; a driven 1/2inch rebar was placed at the southwest corner on the outside wall of Structures E, F, G, and 0 . The structural datum for Structure A was placed near the outside wall, near the only remaining in situ portion. The structural datum was placed near an outside wall for the sutler's store. Several different techniques were used to identify the possible location of structures, as depicted in the 1853 map (Fig. 2), in areas where no modernday surface evidences existed. These techniques included surface survey, probing, dowsing, the use of a metal detector, and predictive estimating.

The ground surface of the entire 11.2-acre tract was surveyed prior to any mapping or testing. Controlled surface survey indicated that, in general terms, all clusters of surface artifacts were restricted to the general locations for structures depicted in the 1853 map (Fig. 2). The survey party flagged the limits of area scatters as well as individual specimens outside primary concentrations. All materials were left in place until the end of the project, at which time they were mapped and collected.

Subsurface probing proved to be very useful in locating buried foundations and remnants of foundations. In a few instances, differential surface vegetation suggested the presence of a buried wall foundation. A probe (ca. 5 feet in length, $1 / 2$ inch in diameter and sharply pointed) was used to detect subsurface foundations, while producing a minimum of damage to the area tested. This procedure was usually conducted in a grid-pattern consisting of six-inch horizontal intervals; the maximum depth of such probes was 2.5-3.0 feet. Probing was also very helpful in locating interior walls associated with extant features. 
An experiment in locating buried foundations was conducted by $I$. Waynne Cox and involved the use of dowsing rods. The experiment provided some interesting results in the vicinity of Structure 0 , where a series of three parallel foundations was indicated in an area where there was no visible sign of foundations. After probing and trenching of the area, three parallel foundation remnants were exposed. For other portions of the site (e.g., Structures $A$ and $D$ ) the experiment provided some rather ambiguous results. Several sma11 "structures," ca. $10 \times 12$ feet were indicated in an area where they could not be substantiated by the 1853 map. These areas were flagged and mapped. The scope of the field work did not allow for further investigations of these areas.

A metal detector was used in an effort to locate the area of the former blacksmith shop and storehouse (Structures $U$ and $V$ ). The 1853 inspection noted the blacksmith's shop was constructed of "adobe," and the storehouse was a wooden structure. There were no surface indicators for either structure; the area is densely overgrown by two-to-three-foot high grasses and herbaceous plants. Malcom Johnson used a metal detector and scanned a 10,000-foot-square area in the vicinity indicated on the 1853 map. Metal detector detection signals within this area were marked by surveyor's pinflags and plotted on the site plan map (Fig. 4). The limited scope of this project did not allow time for probing or trenching. Future work at the site should specifically target this area.

Archaeological testing in areas of suspected foundations consisted of shove test probes (12 inches in diameter) and linear trenchs. Shovel tests were most often used in a "sondage approach" which is designed to provide vertical profiles necessary for the recognition of the sequencing of strata. Sma11 test trenches, usualiy about one-foot wide and of various lengths, were excavated perpendicular to suspected wall foundations. By trenching across remnant and intact foundations, the maximum width and present condition of buried wall sections could be observed and photographed. This method provided the basis for projecting intersecting interior walls, fireplaces, and outside/inside wall corners.

The preceding techniques were used to locate structural remains; the specific locations to test for structures were deduced by predictive estimating. The 1853 inspection map of Fort Martin Scott (Fig. 2) represents a horizontal depiction of structural relationships. The map is not drawn to scale and is of questionable accuracy. For example, Structure 0 is listed as consisting of " 3 rooms and a sergeants room, 48 by 16 feet, constructed of $10 \mathrm{~g}$." Our testing established that the outside dimensions for Structure 0 were actually ca. 80 feet 7 ong by 20 feet wide.

The 1853 map was, from the onset of this project, considered to be a fair representation of the number of structures that had existed in 1853. Horizontal distances, structural dimensions, and materials used to construct depicted structures were questionable. The field referencing systems and scaled site plan map provided a method by which to assess the accuracy of the 1853 map. This information was 1 ikewise used to project the horizontal relationships among depicted structures for which no visible evidence remained. 
The somewhat standardized pattern for mid-19th-century military fort construction simplified the predictive model for buried structures at Fort Martin Scott. Typically, a fort consisted of two rows of structures paralleling the long axis of a centrally located parade ground. Generally, one row consisted of officers' residences and the other of enlisted barracks. At both ends of the parade ground (short axis), single structures, such as an administrative building, guardhouse, or commanders' residence, were often placed. Support facilities such as the hospital, laundry, storehouse, sutler's store, etc., did not front on the parade ground but occupied areas away from, however still directly accessible to, the main parade ground.

The estimated center line for the Fort Martin Scott parade ground was calculated by the following method. The guardhouse (Structure $N$ ) measured ca. 63 feet across its long axis which was oriented roughly $5^{\circ}$ west of magnetic north. A temporary datum was placed at the midpoint of the wall facing the parade ground. A transit was then used to turn a $90^{\circ}$ angle perpendicular to the long axis of the guardhouse; an east-west base line was then established which transected the length of the parade ground. This east-west base line (640 feet in length) extended uphill and terminated in the vicinity of the former commanders' residence (Structure A). If we had, in fact, reestablished the true center line of the parade ground, it should have bisected Structure $A$ at its midpoint. Unfortunately, very little structural evidence could be found by which to establish the precise location, size, and alignment of Structure A. However, the base line terminated within ca. 10 feet of the area where partial foundation remnants of Structure A were isolated (Fig. 4).

A second base line ca. 155 feet north of the main site base line was established along the row of officers' residences (Fig. 4). The base line was designed to project the relative location for the wall foundations which fronted on the parade ground. The southern wall foundation for Structure $G$ was cleared of vegetation and dirt; a transit was set up at the southeast corner. The relative location of this wall was projected uphill past the location of Structure $B$ and was established by string and nails. If all five dwellings had been built in a row, as depicted in 1853 (Fig. 2), we now knew approximately where the front walls for the other four structures should be located. The projected locations for two structures ( $D$ and $E$ ) were further investigated. Time did not allow for investigations at all five structures.

This structural base 1ine was remarkably accurate in predicting the location for Structures B and E. All five dwellings appear to have been oriented to within $2^{\circ}$ of each other along the same east-west axis. Additionally, the structural base line and the main site base line were nearly parallel to each other at a distance of $\mathrm{ca}$. 150 feet. This suggests that predictive estimating can probably be used to locate the row of structures immediately south of the parade ground.

\section{RESULTS OF FIELD INVESTIGATIONS}

The CAR field investigations resulted in the identification and test excavations at eight different structural remains. Three additional areas were intensively surveyed but did not result in the identification of 
foundation remnants. A detailed description of these 11 specific locations, within the larger context of Fort Martin Scott, is now presented.

\section{Structure A (Post Commanders' Residence)}

Structure $A$ is located on the west side of the former parade ground and is within Ca. 100 feet of the present Highway 290 roadbed (Fig. 4). The 1853 Freeman Inspection Report described this structure as a log building with four rooms $15 \times 17$ feet in dimensions with porches front and rear (Fig. 2). The only remaining surface indications for this structure consisted of a few scattered limestone rocks and a short section of stone wall (Fig. 5,a).

The front of this structure would have faced east towards the parade ground. The exposed short wall section is oriented roughly east-west and represents a remnant of the north wall foundation. Flat shovels were used to scrape off the upper few inches of soil in all directions from the extant wall section. Additional stones, roughly oriented north-south, were found to intersect the short wall section at a $90^{\circ}$ angle. These two wall sections appear to represent the northeast corner of Structure $A$ and the foundation footer for the front porch (Fig. 6,a).

Three shovel tests were placed in the vicinity of Structure $A$, one inside and two outside the structure. In shovel test I, artifacts were found to a depth of 15 inches, decomposed mortar from 15 to 18 inches, with culturally sterile red clay below 18 inches. In shovel test II, the same red clay was encountered at three inches below ground surface and continued to a depth of 18 inches. At 18 inches in depth, limestone bedrock was encountered; no artifacts were recovered from shovel test II. In shovel test III, red clay began at four inches in depth and extended to the bottom of the hole (19 inches). Shovel test III did not produce any artifacts. The results of shovel test I, located inside the foundation remnants, suggest that the original ground surface during the occupation of the structure was buried beneath as much as 18 inches of overburden.

Artifacts recovered during the wall cleanings and shovel testing were few and consisted of square nails, broken glass, and animal bones. The largest number (188) was found on the ground surface in front of the structure, in the vicinity of the former porch area. Recovered materials consisted of a variety of glass fragments (black, green, clear), several different ceramic types (hand painted, edge decorated), and 90 square-cut nails (Table 3 ). In the vicinity of Structure A was the location for "Braeutigam's Garten" of the 1880s. There were no obvious surface indications for the locations of the saloon, dance hall, or store. A stone-lined well, similar in dimensions and construction to the well near the guardhouse, is also located in the vicinity of Structure A.

\section{Structure B (Officers' Quarters)}

Structure B is the westernmost structure in the north row of officers' quarters (Fig. 4). The 1853 Freeman Inspection Report describes the structure as adobe, two rooms, $10 \times 12$ feet with porches front and rear 


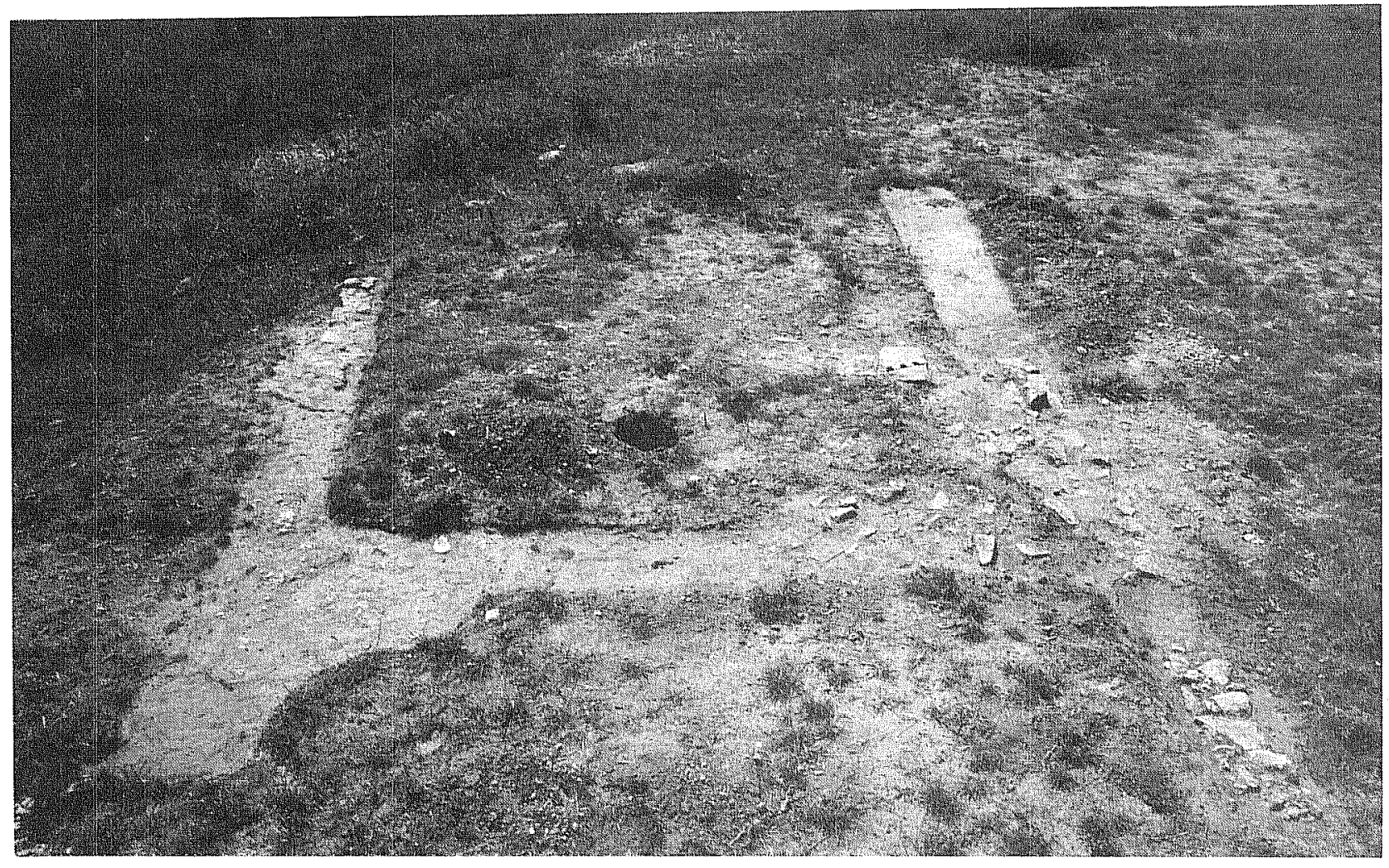

a

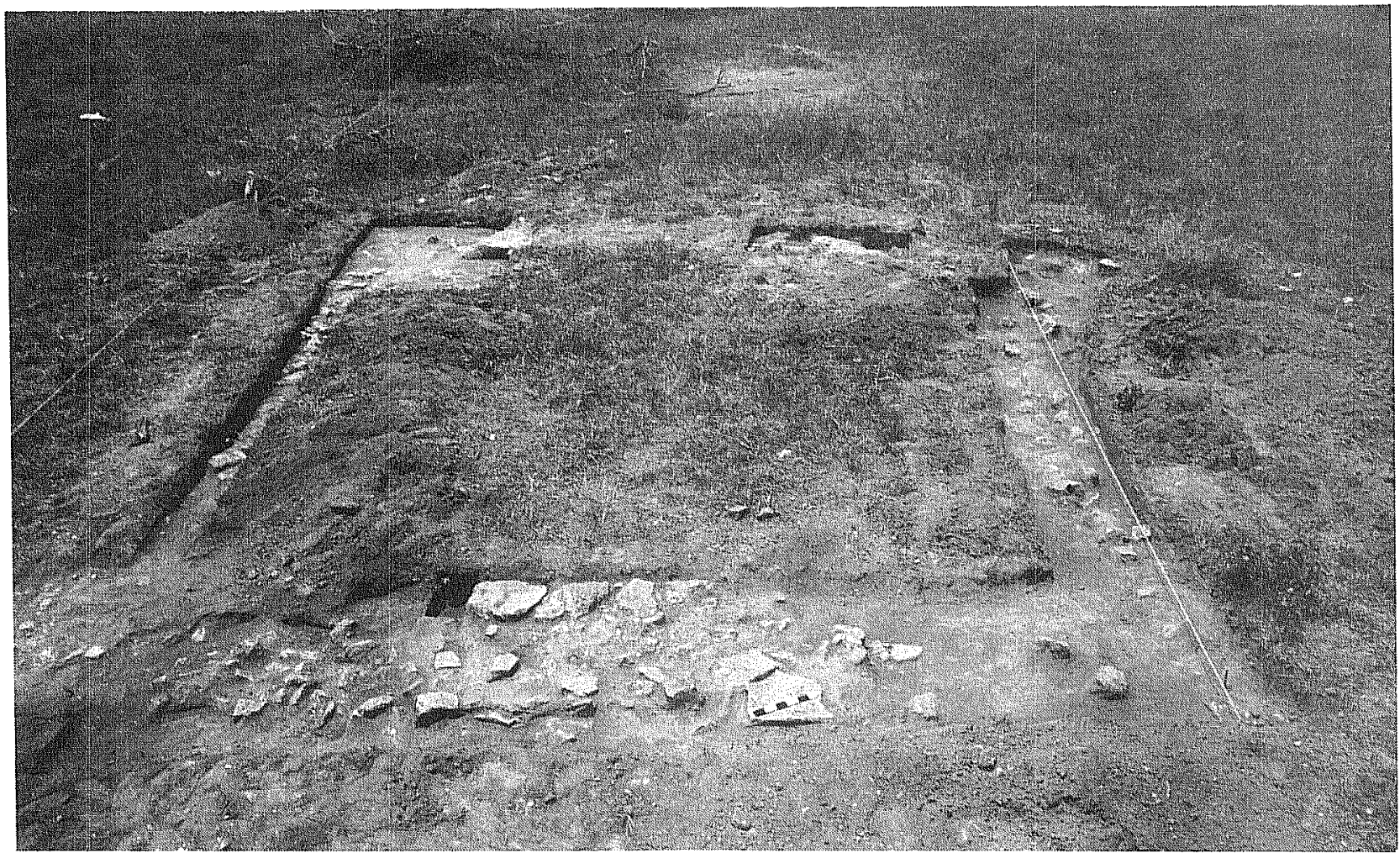

b

Figure 5. Foundation Remnants for Structures $A$ and $B$. a, Structure A; b, Structure B. 


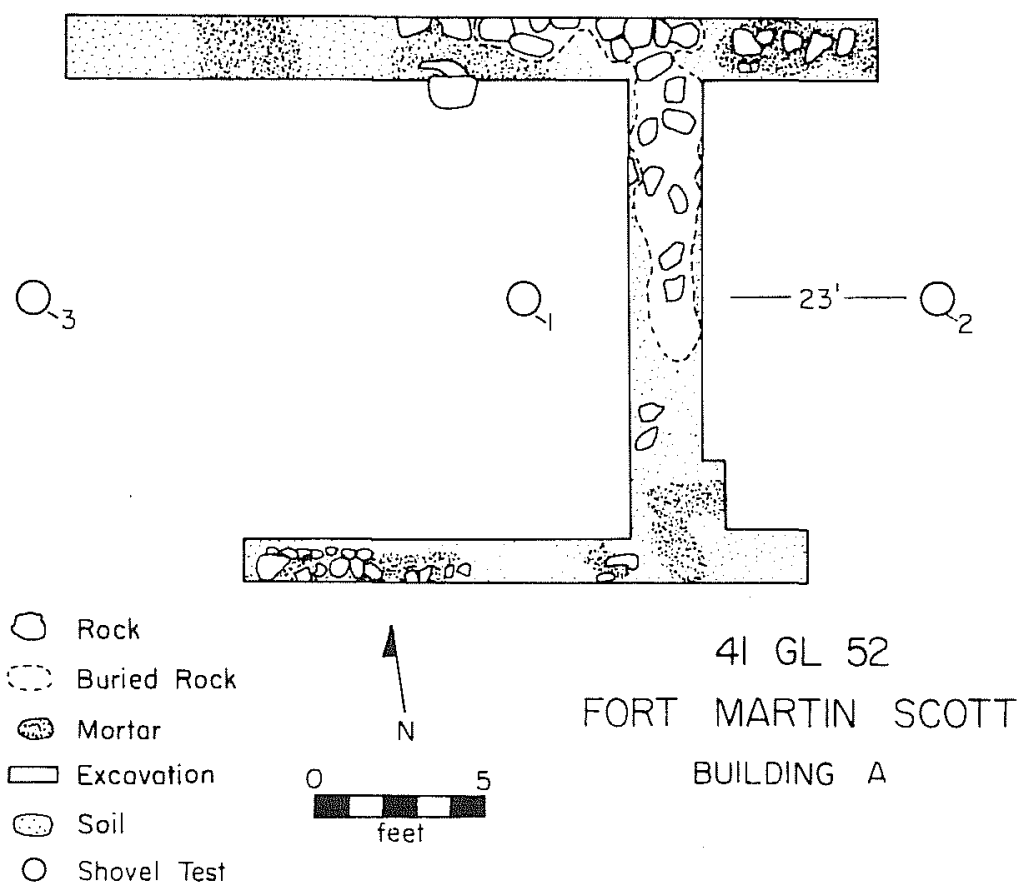

a

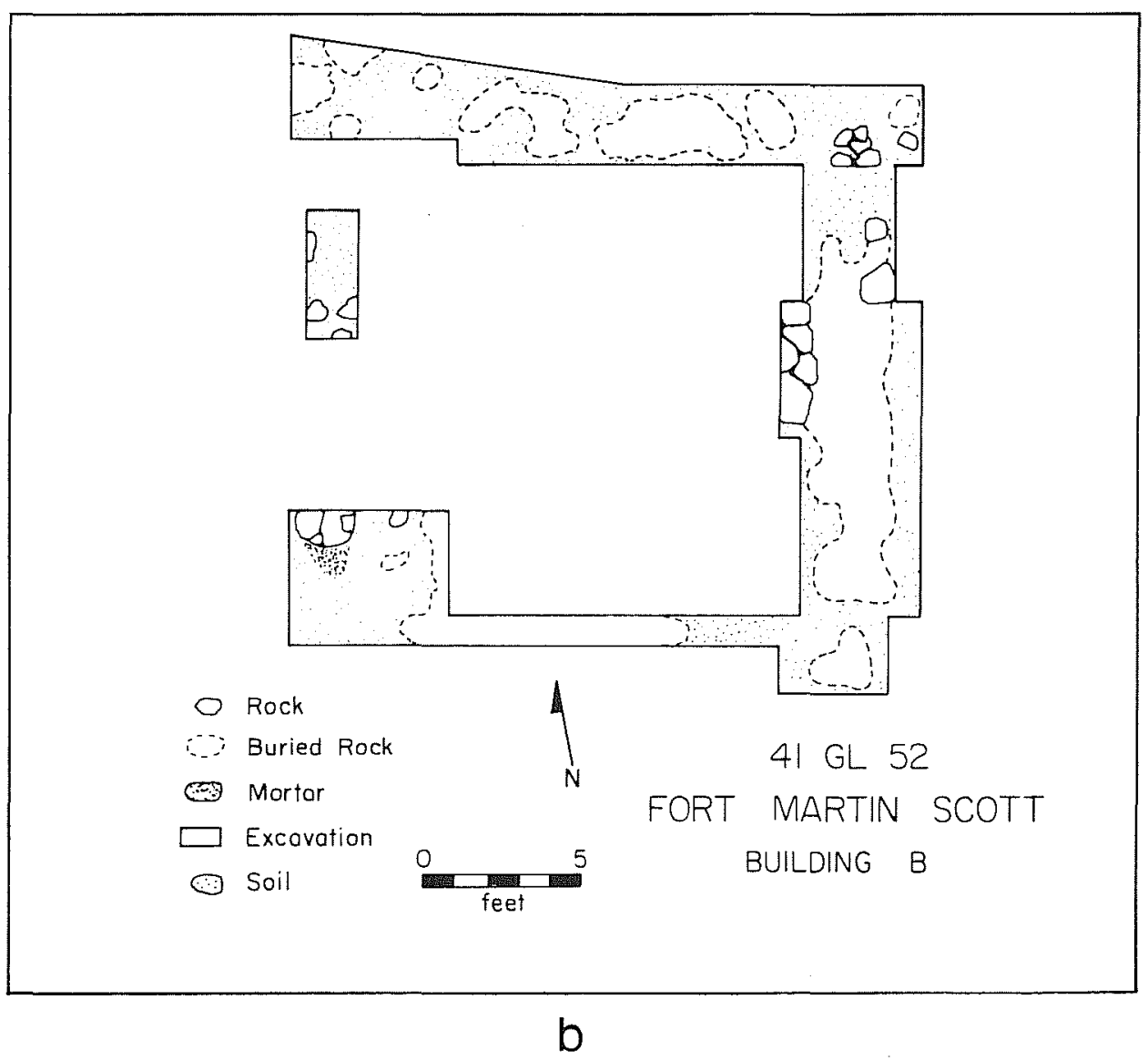

Figure 6. Floor Plan Drawing of Structures A and B. a, Structure A; b, Structure B. 
TABLE 3. PROVENIENCE FOR ARTIFACTS RECOVERED AT FORT MARTIN SCOTT

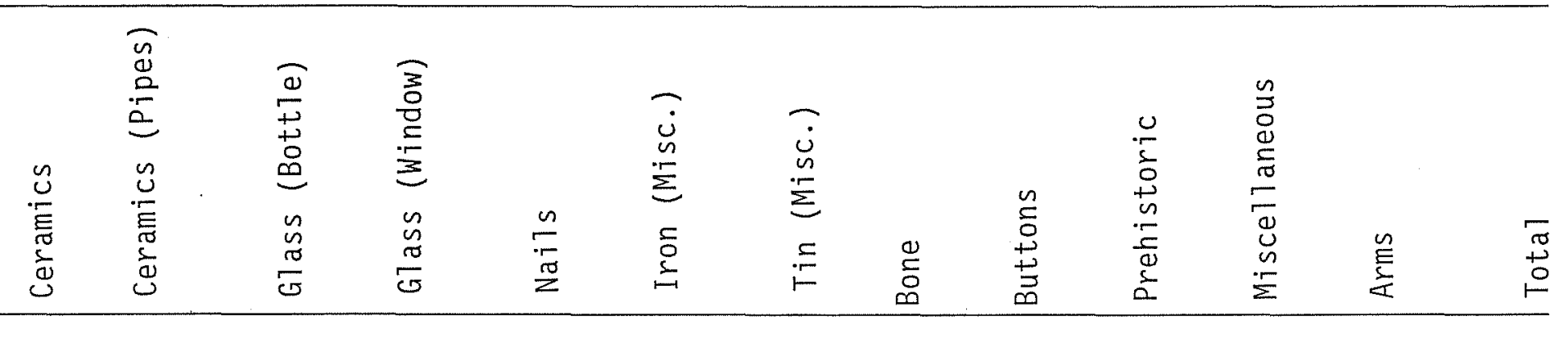

Structure A $\quad 30$

Structure B

Structure E

Structure G

Structure J

Structure L

Structure M

Structure N

structure 0

30
1
2
2
-
-
3
-
2

Survey Area 1
(Structures $R, S$ )

$-62$

$62 \quad 2$

90

2

Survey Area 2

(Structures U,V)

Survey Area 3

(Structure K)

General Surface 6

$8 \quad 1$

$\begin{array}{lll}19 & 2 & 1\end{array}$

$\begin{array}{rr}- & 6 \\ 16 & 2 \\ 1 & - \\ 3 & - \\ 2 & 1 \\ - & - \\ 16 & - \\ - & - \\ 2 & 4 \\ 1 & 10\end{array}$

-
1
-
-
-
-
-
-
4

-

$\begin{array}{ll}- & - \\ -\quad\end{array}$

75

3

$20 \quad 1$

$93 \quad 1$

$-$

$$
-
$$$$
\overline{2}
$$

196

2

1

\begin{tabular}{lllllllllllllll}
\hline Total & 110 & 7 & 135 & 21 & 329 & 48 & 42 & 23 & 5 & 15 & 3 & 7 & 754 \\
\hline
\end{tabular}


(Fig. 2). The structure fronted on the parade ground. There were a few scattered rocks on the surface to indicate the general vicinity of the structure. The projected structural base line was used to suggest the area to be tested.

With the aid of the probe, a discrete line of rocks in the center of the building was located ca. five inches below ground surface (Fig. 6,b). This line of rocks eventually turned out to be the foundation for the chimney base. The relative location for the rear (north) wall and front (south) wall was projected from the chimney base. String lines were also established for the suspected locations of the west and east walls. All wall projections were excavated to a depth of $\mathrm{ca} .10$ inches. The north wall consisted of a scatter of stones and deteriorated mortar (Fig. 5,b). A small piece of finished plaster, finer grained and much whiter than the mortar, was found along the north wall and appears to have been painted or whitewashed on one surface. The south wall projection did not produce any intact portions of a foundation. There is a layer of stone rubble intermixed with deteriorated mortar spread over most of the southern part of the building. Excavation of the west and east wall projections produced similar results.

A total of 75 artifacts was recovered from the ground surface and archaeological testing (Table 3 ). These materials included tin can scraps, window glass, a button (Fig. 16,p), two clay pipe fragments (Fig. 16, $i, j$ ), and 29 square-cut nails. A total of 52 plaster and five mortar samples was collected.

\section{Structure E (Officers' Quarters)}

Structure $E$ is located in the north row of the officers' dwellings (Fig. 4). The 1853 Freeman Inspection Report described the structure as adobe, two rooms, $14 \times 16$ feet in dimensions with porches front and rear (Fig. 2). The structure fronted on the parade ground. There were several extant portions of foundation clearly visible before testing began at this structure.

The extant portions of walls were cleaned (Fig. 7,a). Additional trenching and hand excavation were necessary to completely uncover the west (Fig. 7,b) and east walls (Fig. 7,c). Both the east and west walls contained a foundation for a chimney base. Both were located in the center of the walls (Fig. 8,a). Two interior walls, oriented roughly north-south, were also identified and excavated. Only short sections of the front (south) and back (north) walls were cleared.

A metal detector was used to survey both the inside and outside areas of the wall foundations. The instrument registered 21 detection signals on buried metal objects. The distribution was rather limited; nearly all detection signals were located within 12 feet of the north wall. The location along this wall could suggest that the pattern represents a fallen porch with the detection signals being nails which had once held it together.

During the initial ground surface survey of Structure $E$, a total of 30 artifacts was surface collected (Table 3). These included 15 square-cut nails, two undecorated whiteware sherds, and a few window glass fragments. 


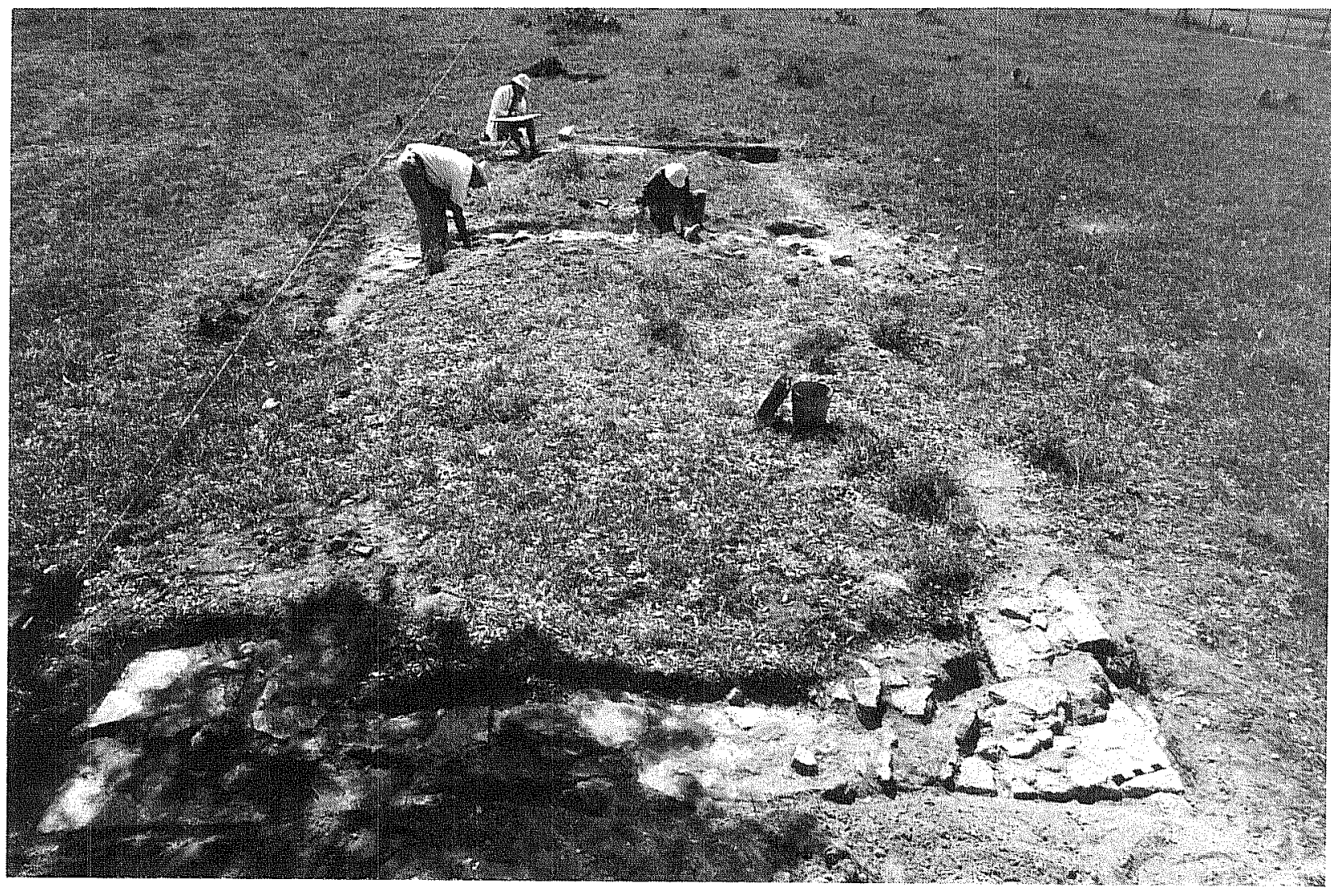

2

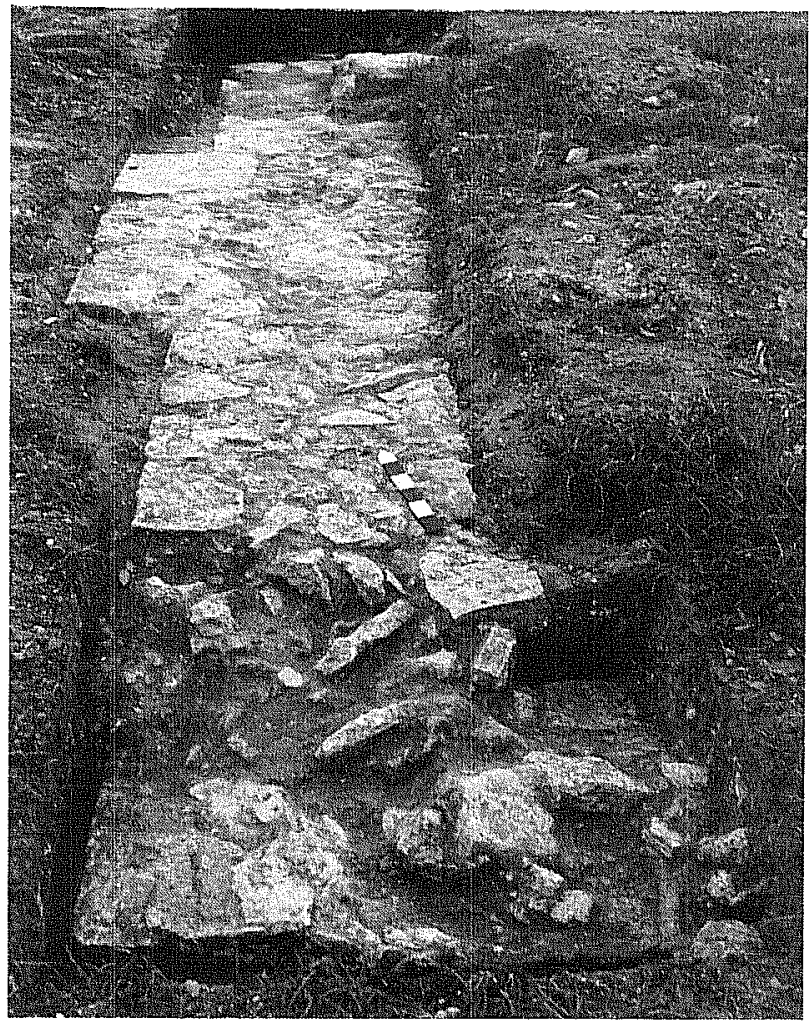

b

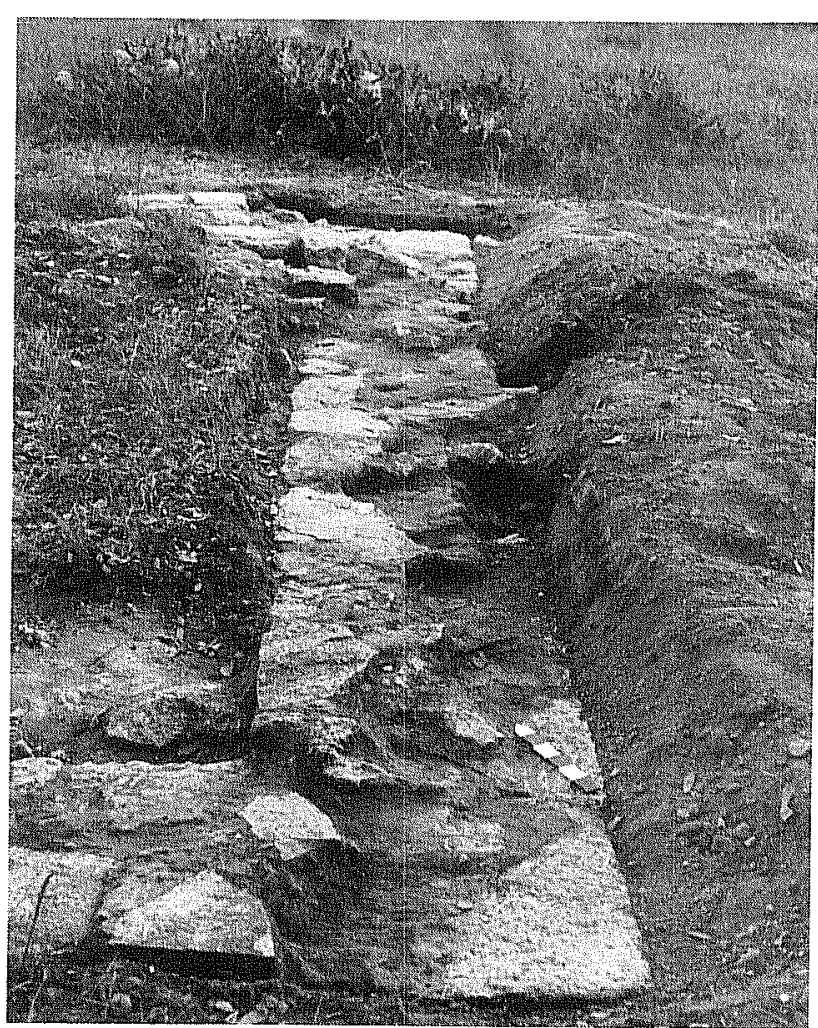

c

Figure 7. Foundation Remnants for Structure E. a, foundation cleaning; b, west wa11; c, east wall. 


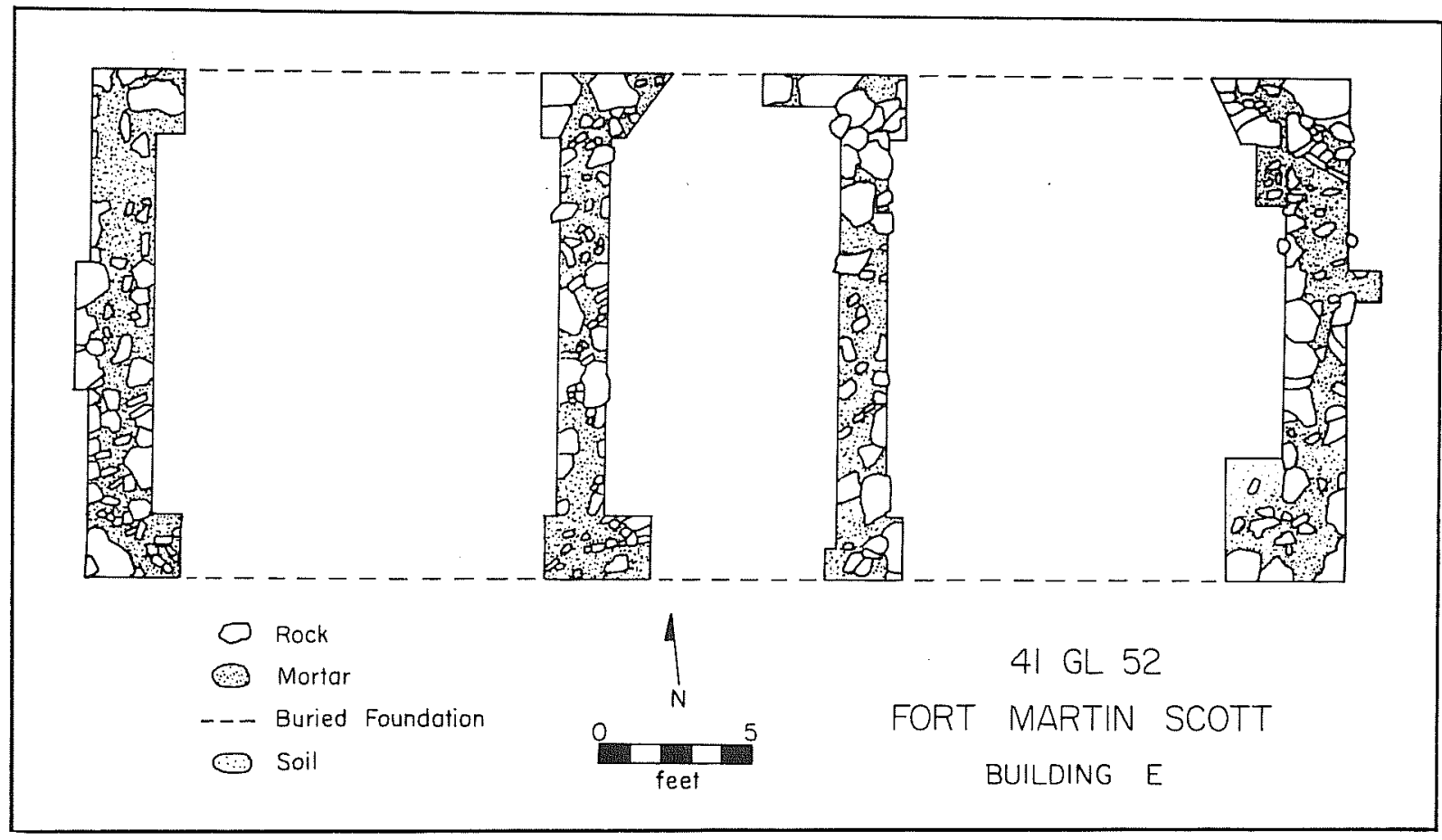

a

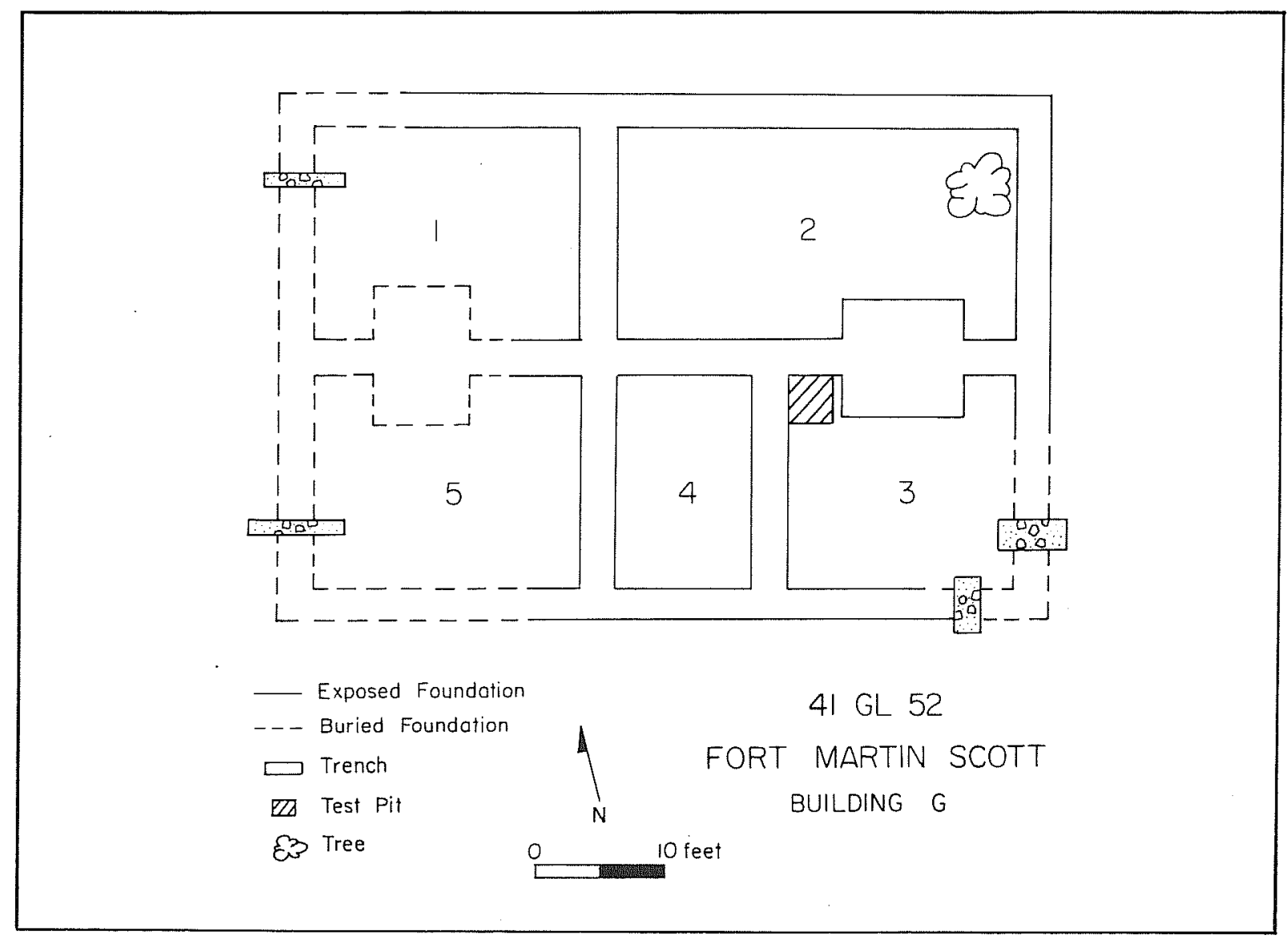

b

Figure 8. Floor Plan Drawing of Structures E and G. a, Structure E; b, Structure G. 
The archaeological testing at Structure $E$ produced no artifacts; three plaster samples were recovered.

\section{Structure G (Officers' Quarters)}

Structure $G$ is the easternmost structure in the north row of officers' quarters (Fig. 4). The 1853 Freeman Inspection Report described this structure as adobe, four rooms with a basement, and $16 \times 17$ feet in dimensions; there was no mention of porches (Fig. 2). About 75\% of the foundation for this former structure was exposed prior to testing (Fig. 8,b).

A total of two test trenches was excavated at a $90^{\circ}$ angle to the suspected location of the west wa11. Both test units evidenced small amounts of mortar and rubble but without any in situ sections of wal1. Excavation of the western one-third of the south wall produced similar results. Two additional test trenches (ca. 12 inches deep) near the southeast corner of the south wall also produced similar results. The areas currently exposed represent the only sections of foundations remaining from Structure G (Fig. 9,a).

The probe was used to test the interiors of all four rooms. The comparative resistance of soils tested would indicate that the basement was located in Room 2 of the structure which is also the largest of the four rooms. A second foundation for a chimney base was found centrally located in the common wa11 between Rooms 1 and 5 .

A single excavation unit (three feet square) was placed in the northwest corner of Room 3 in an effort to determine the maximum depth of the two nearby wall foundations. At 15 inches below ground surface, the foundation terminated. Two stratigraphic zones were recognizable, Zone I (0-6 inches) and Zone 2 (6-15 inches below the surface). Both zones contained rubble and mortar throughout. A total of 23 artifacts was recovered; 18 .of which were found in subsurface contexts (Table 3 ).

\section{Structure $\mathrm{H}$ and $\mathrm{J}$ (Sutler's Store)}

The sutler's store was located on the northeast corner of the parade ground in the vicinity of the weather-boarded barn that currently exists in this area (Fig. 4). The 1853 Freeman Inspection Report noted the sutler's store consisted of two structures ( $H$ and $J$ ), built by L. G. Capers, but provides no description or size for either building (Fig. 2). There are no visible surface indications for the sutler's store.

The barn which now stands in this area (Fig. 3, C) was constructed by a Braeutigam family member sometime after 1884 . The Braeutigam family history (Sauer n.d.) states that this barn was constructed with the weather boarding from the former dance hall and saloon ("Braeutigam's Garten") that was torn down following John Braeutigam's murder in 1884.

The probe was used to test the area in front of the barn. Several detection signals were investigated, but were found to be isolated stones. An intact portion of foundation, with adjoining cross wall, was eventually isolated 


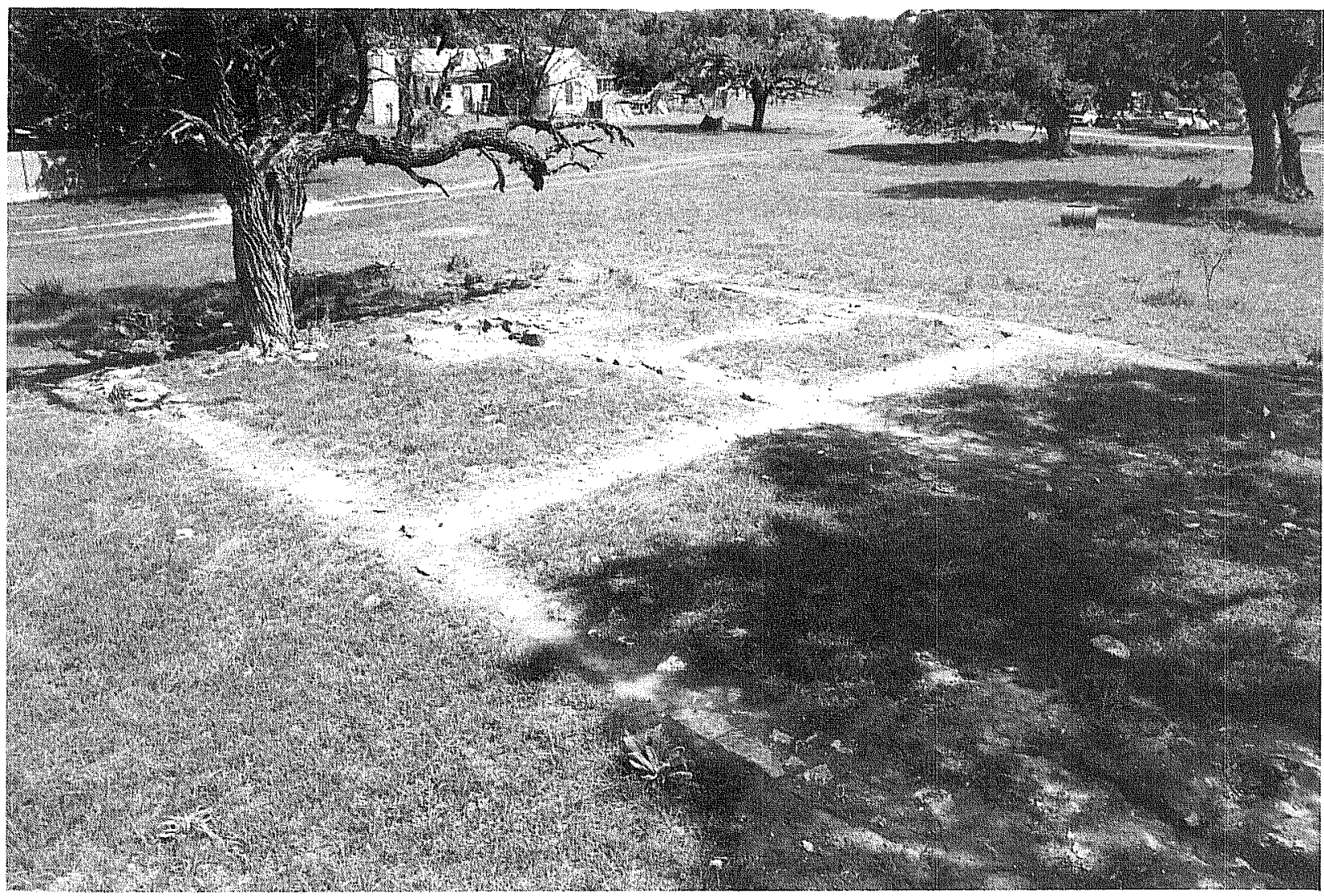

a

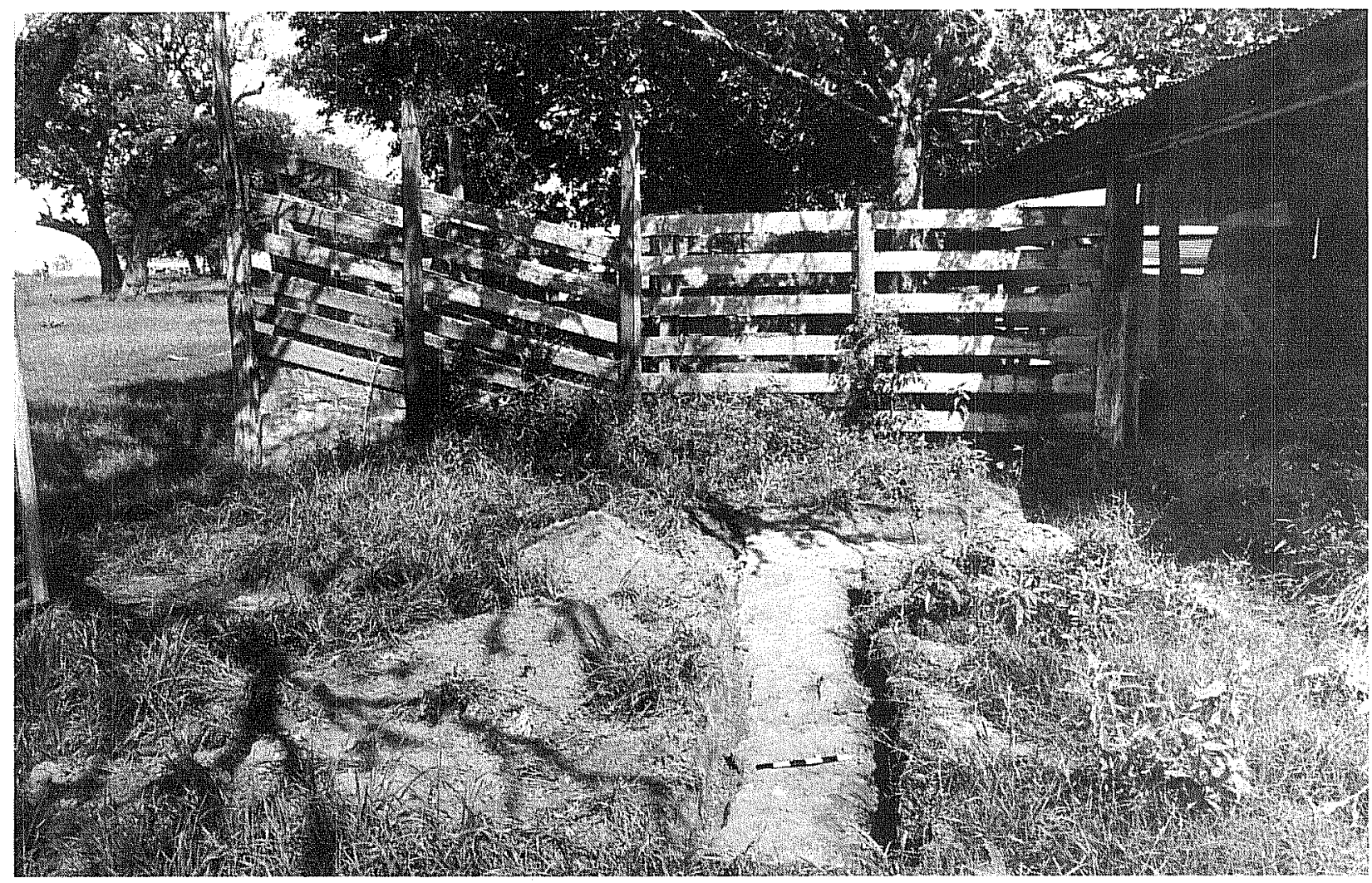

b

Figure 9. Foundation Remnants for Structures $G$ and $J . a$, Structure $G ; b$, Structure $\mathrm{J}$. 
(Fig. 9,b). The main wall section (outer wall) was ca. two feet thick, while the cross (interior) wall was ca. 18 inches thick. Both walls were composed primarily of rubble and deteriorated mortar (Fig. 10).

The cross wall was oriented roughly north-south and adjoined the main wall at a $90^{\circ}$ angle. The northernmost portion of this wall appears to have been destroyed by the construction of the barn. The main east-west wall remnant extends to the east for at least 15 feet and is buried beneath 6 to 13 inches of earth. The western limits of this wall were not explored. These remnants may represent Structure J; remnants for Structure $H$ are most probably inside the barn. The subsurface soil failed to produce a single artifact.

\section{Structure L (Laundress' Quarters)}

The 1853 Freeman Inspection sketch map depicted the laundress' quarters as being situated on the bank adjacent to Barons Creek near the sutler's store and bake house (Fig. 2). It was described as constructed of $\log$ with dimensions of $20 \times 14$ feet and contained a store room and quarters for the laundry worker(s).

Surface survey of this general area noted a limestone block foundation, roughly parallel to Barons Creek, in the approximate area noted for Structure $L$. No artifacts were found in the immediate vicinity. The extant portion of this foundation, ca. 30 feet in length, was cleared of vegetation with the use of a weed trimmer. An east-west cross wall was also isolated and cleared of vegetation. This cross wall, however, does not intersect the main wall remnant at a $90^{\circ}$ angle. Due to limited field time, concentrated efforts to locate additional walls were not possible. There is still some question as to which wall foundation this extant feature represents. The intersecting cross wall that was documented, which is not perpendicular to the main wall, should be further investigated at some future date.

\section{Structure M (Bake House)}

Structure $M$ is located adjacent to Barons Creek and is ca. 50 feet south of the northeast corner of the property leased by the City to the Fredericksburg Heritage Federation (Fig. 4). The 1853 Freeman Inspection Report described the bake house as a $\mathrm{log}$ structure with dimensions of $14 \times 20$ feet (Fig. 2). The only remaining evidence for this structure is the remains of the foundation for a cut-stone bake oven (Fig. 11,a).

The feature was photographed. The surface vegetation, consisting of medium grasses and herbaceous plants, was removed with the help of a gas-powered weed trimmer. Dimensions of this platform measured 12 feet (north-south) by 13 feet (east-west) with the average wall width at ca. 18-20 inches. Artifacts recovered during cleanup included ceramic sherds, tin scraps, and square-cut nails (Table 3). No evidence for the location of the structure, in relation to the bake oven, was found. 


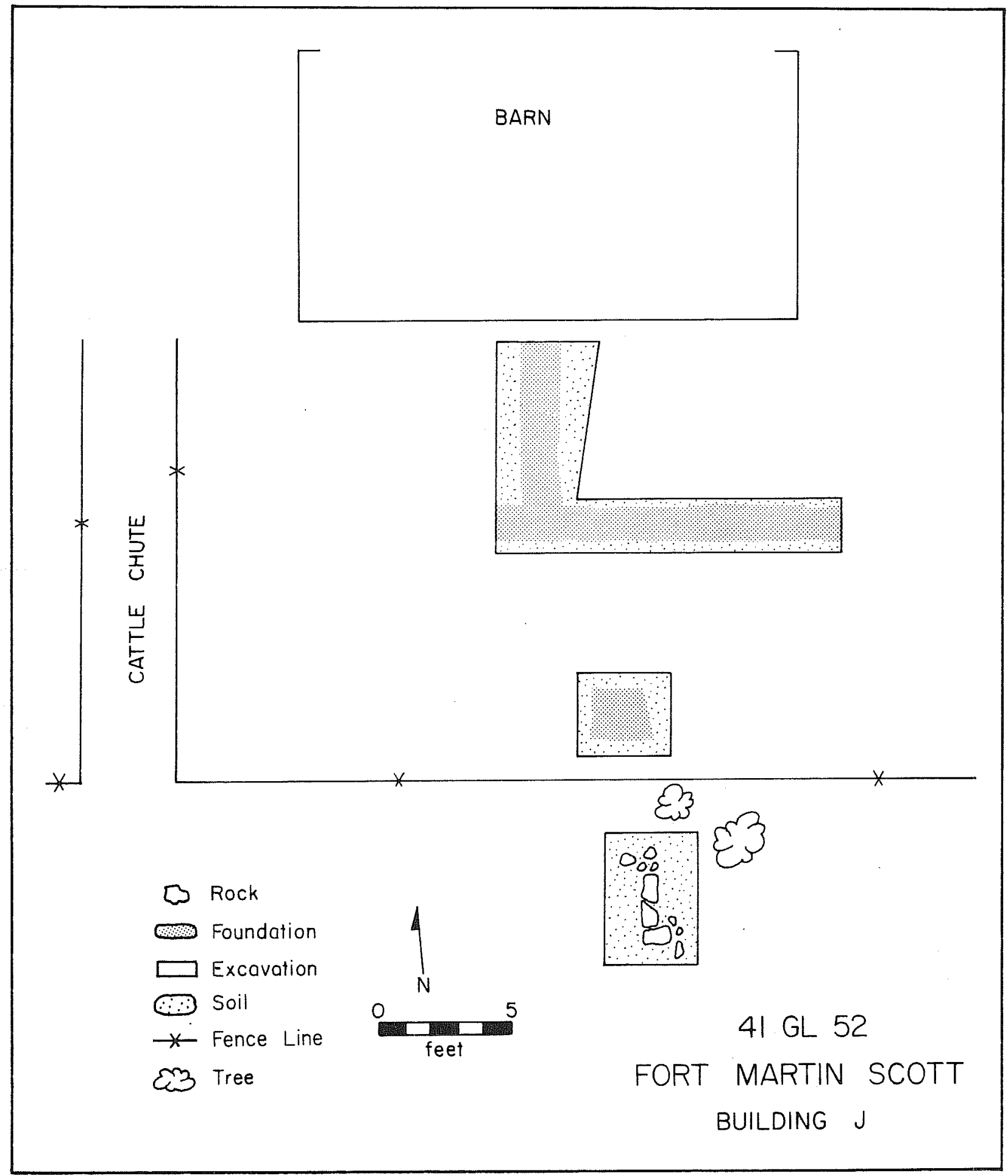

Figure 10. Floor Plan Drawing of Foundation Remains for Structure J. 


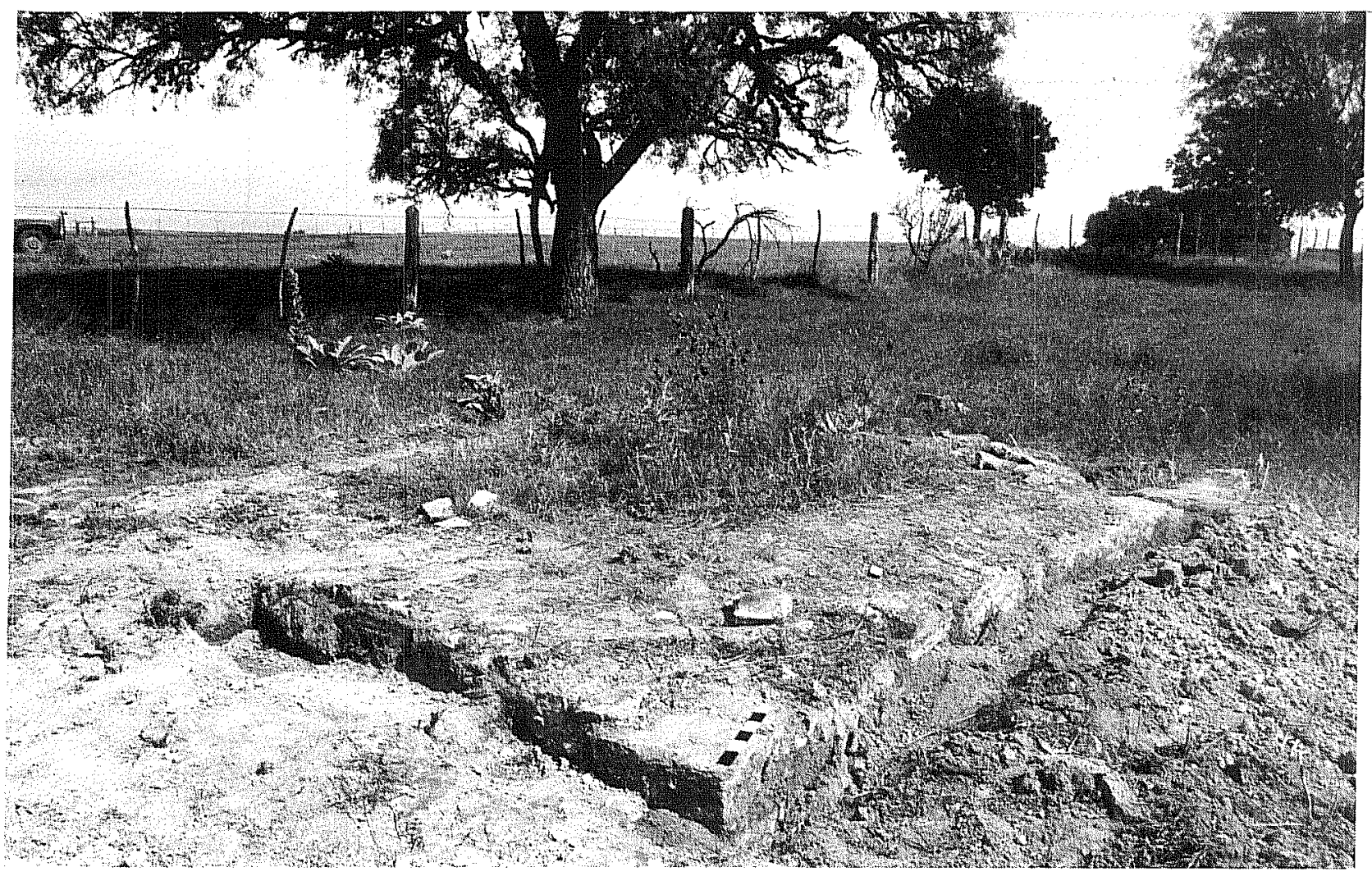

a

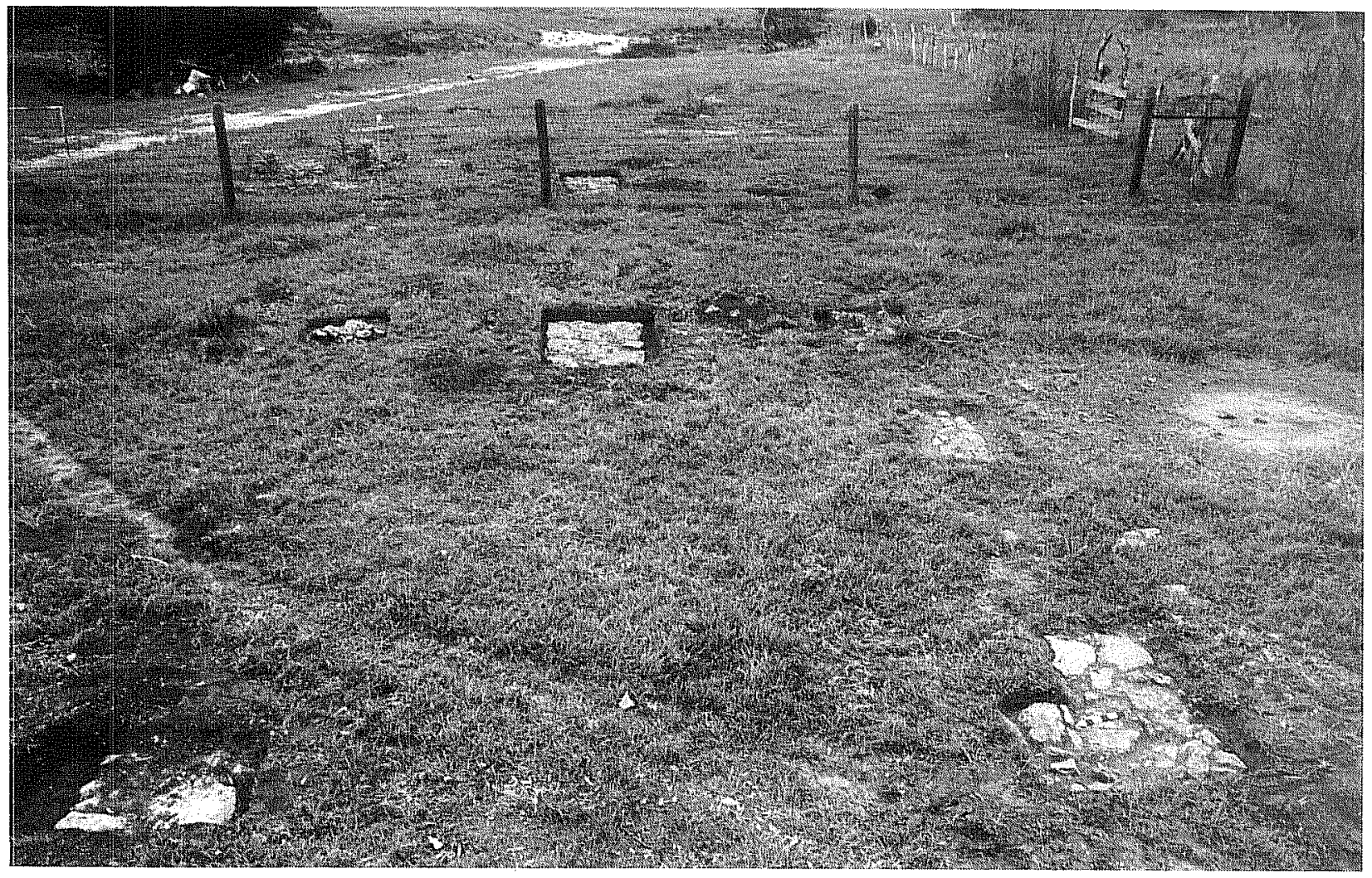

b

Figure 11. Foundation Remnants for Bake Oven and Structure 0. a, bake oven; $b$, Structure 0 . 
Structure 0 (Enlisted Quarters)

Structure 0 is located at the southeast corner of the parade ground. It is one of two structures $(0, P)$ designated as enlisted quarters, and it was of sufficient size to accommodate one company of soldiers. The Freeman Inspection Report described these structures as both constructed of logs, 48 $x 16$ feet in dimensions, each with three rooms plus a single room. This project concentrated its efforts on Structure 0 ; there were no visible surface indications for its precise location (Fig. 11,b).

The surface vegetation in the vicinity consisted of short grasses. An experiment, using dowsing rods, was tried first before using the probe or shovel tests to investigate the subsoil. The procedure involved walking the area in multiple transects and marking suspected areas with surveyor's flags. The experiment suggested that there were three parallel foundation walls, one of which was located in the plowed field south of the fence. Three separate cross walls were also indicated. A total of 13 units was excavated; their locations were designed to specifically located corners, midsections of walls, and fireplace bases (Fig. 12).

Following the completion of shovel testing, all units were drawn and photographed. Archaeological testing revealed three parallel wall foundations (east-west), three cross wall foundations, and two fireplace bases centrally located within interior cross walls (Fig. 12). A total of 126 artifacts was recovered, including a horseshoe from one of the interior rooms (Table 3). Measurements established that the foundations were for a structure with three rooms, $19 \times 21$ feet each, with foundations ca. 2.5 feet in width. A disturbance was noted in the area of shovel test $V$ and $X$. A shallow ground depression was also noted in this area. The easternmost foundations abruptly terminated in the depression which was composed of red clay. All other foundation remnants were in very dark brown matrix.

\section{Survey Area 1 (Structures $\mathrm{R}$ and $\mathrm{S}$ )}

Survey Area 1 corresponds to the location for the enlisted quarters on the south side of the parade ground (Fig. 2). There are no visible surface indications for their former locations. Several ground surface anomalies, consisting of shallow depressions and/or slightly elevated surfaces were probed but provided ambiguous results. Surface vegetation in this area is generally sparse. Intensive surface survey isolated three discrete clusters of artifacts within the larger area designated as Survey Area 2 (Table 3).

The main artifact scatter was limited to an area ca. 50 feet (east-west) by 40 feet (north-south). The ground surface had little to no vegetation and exhibited numerous erosional rivulets produced by sheet wash erosion. A total of 19 complete square-cut nails (Fig. 13), two pipe fragments, two buttons, one cartridge case, and several glass fragments was found randomly scattered across the area. A second smal1 concentration of artifacts (Fig. 14) was isolated in the western half of Survey Area 1: several square-cut nails, .36 caliber and .44 caliber lead balls (Fig. 16,0,q), a U.S. military button (Fig. 16,d), and two percussion caps for use on military muskets (Fig. 16, 1,m). 
FORT MARTIN SCOTT / Results of Field Investigations

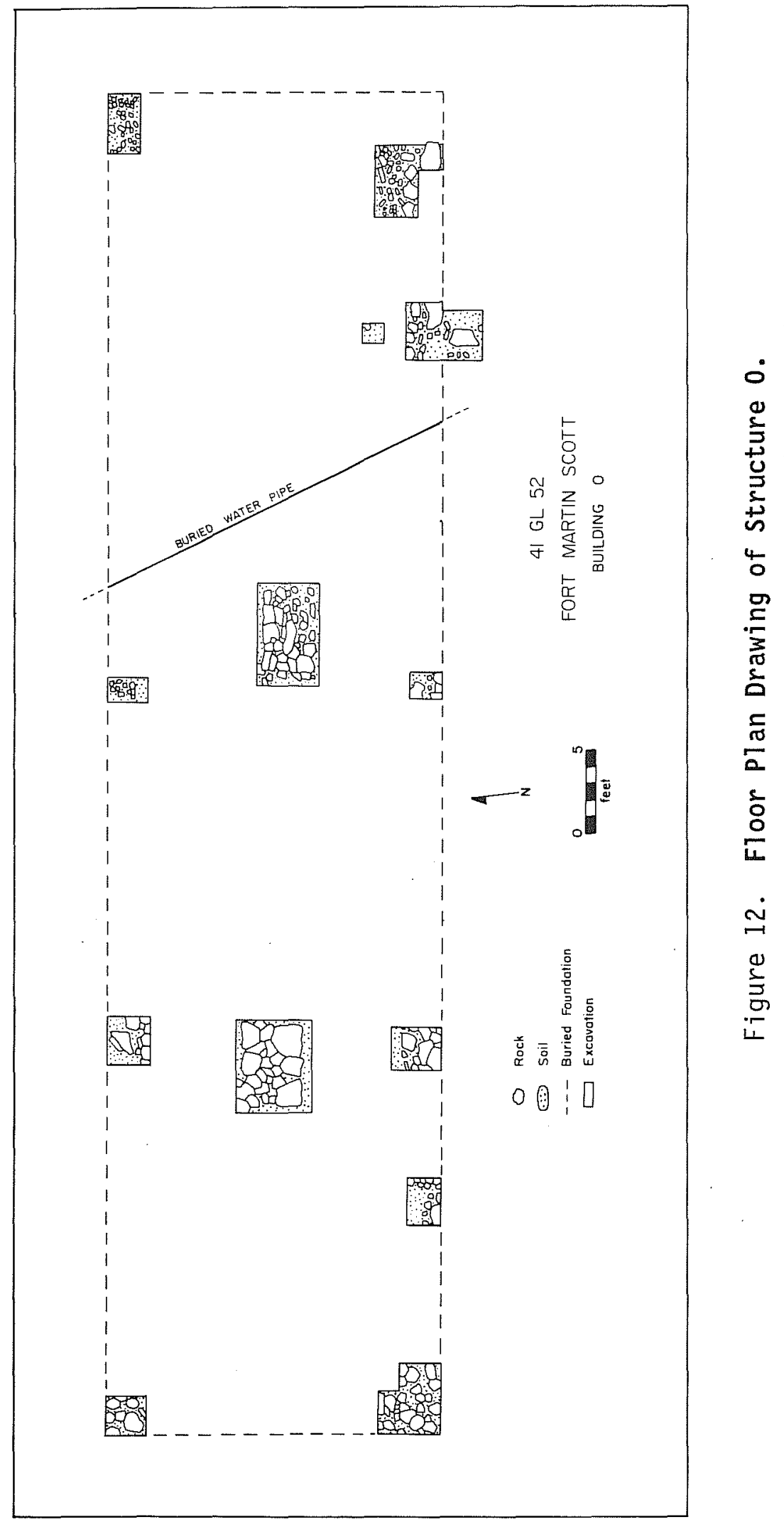


FORT MARTIN SCOTT / Results of Field Investigations

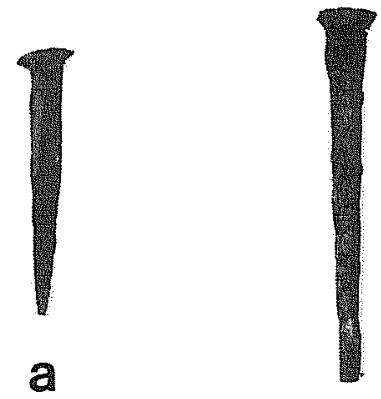

b

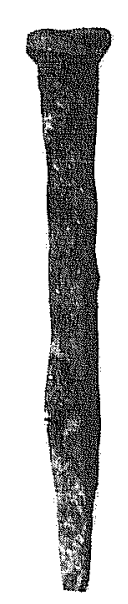

f

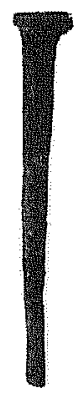

c

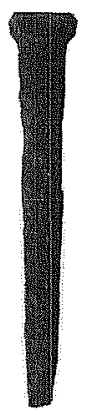

d

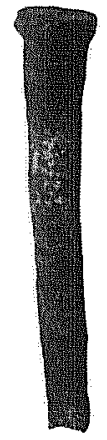

e
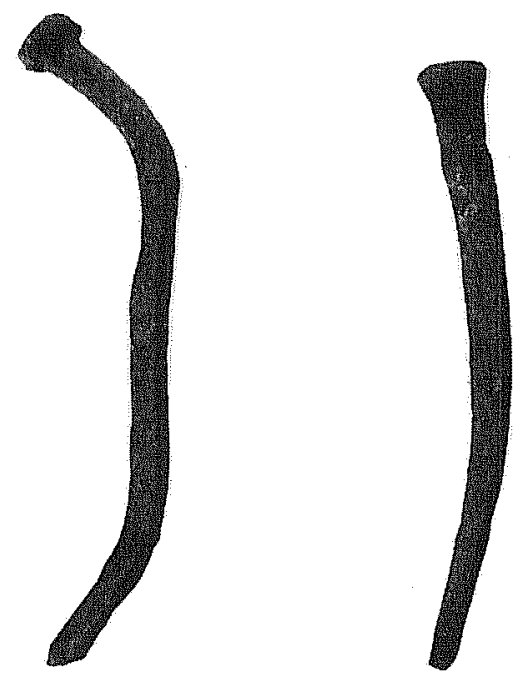

0

$5 \mathrm{~cm}$

h
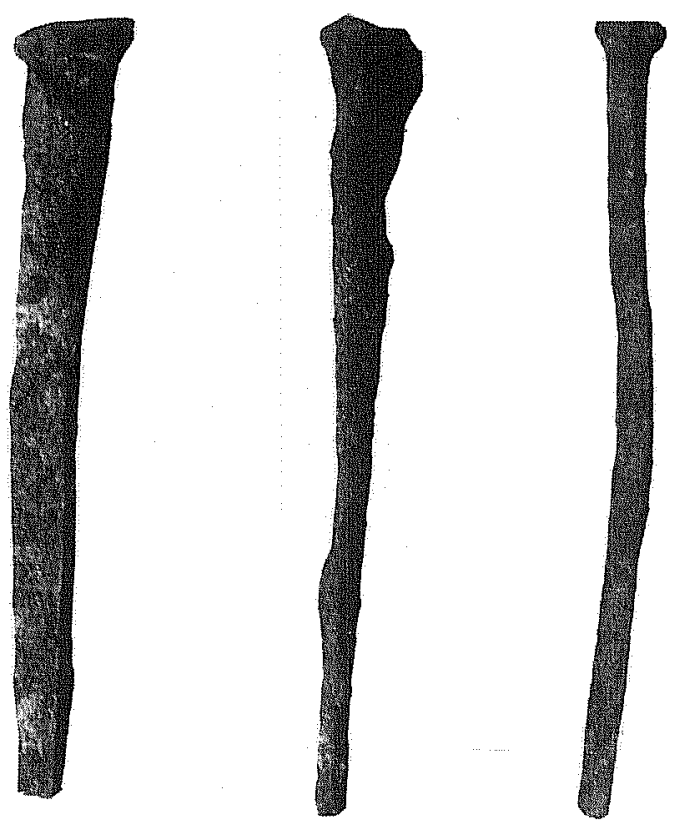

k

m

n

Figure 13. Square-Cut Nails Recovered from Survey Area 1. 


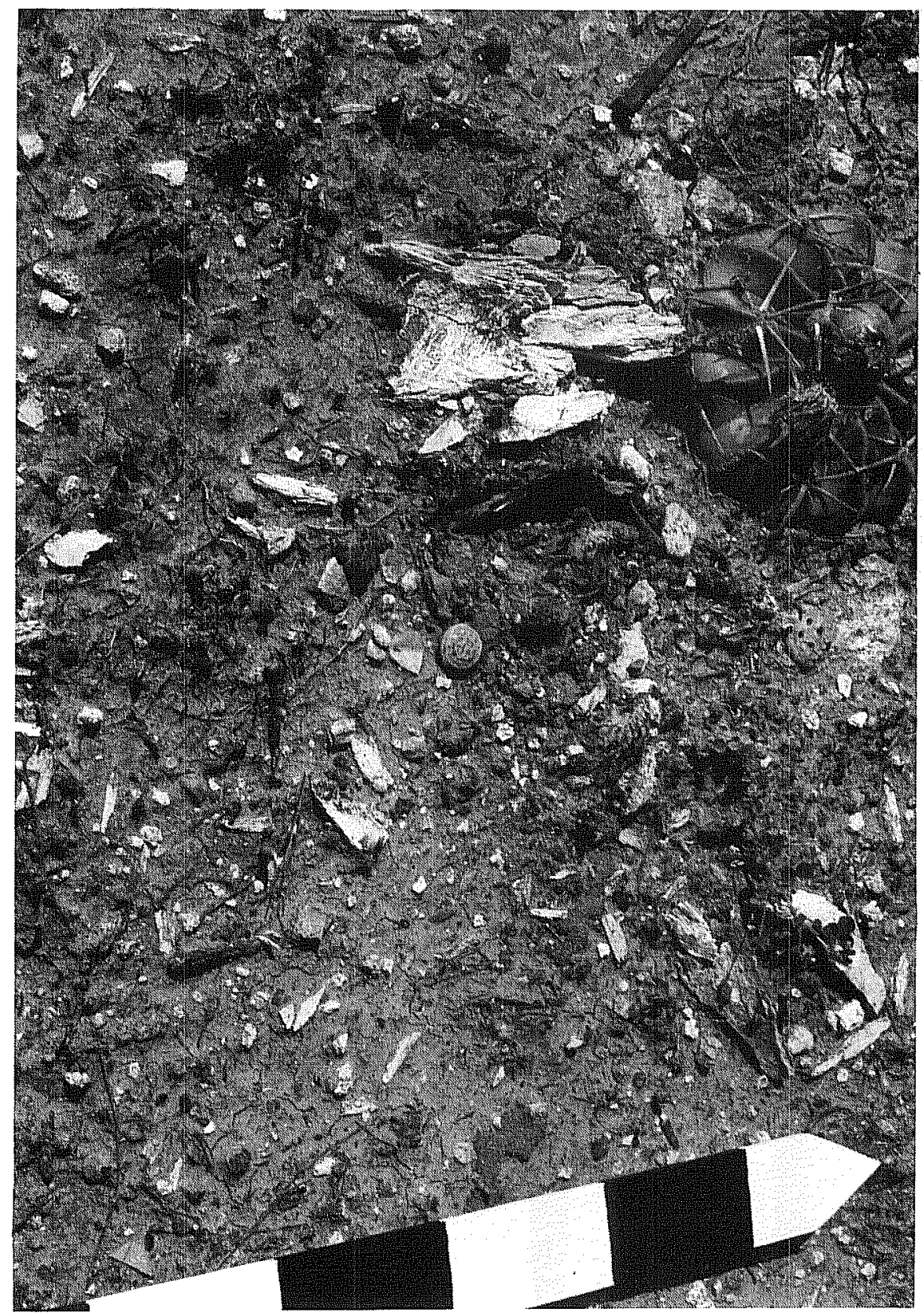

Figure 14. Artifact Scatter in Survey Area 1. 
Directly east of this main scatter, a third surface scatter (Area T-east end) was found. This scatter was separated from the main scatter by ca. 45 feet and consisted primarily of square-cut nails. A total of 64 nails and three glass fragments was isolated within an area ca. 25 feet square.

All three artifact scatters within Survey Area 1 correspond to the general area of the former enlisted barracks 1 abeled as Structures $R$ and $S$ on the 1853 sketch map (Fig. 2).

\section{Survey Area 2 (Structures $U$ and $V$ )}

Structures $U$ and $V$ are the southernmost buildings depicted on the 1853 sketch map of Fort Martin Scott (Fig. 2). There are no surface indications for either structure. The present-day vicinity for their location consists of a dense coverage of medium grasses and herbaceous plants; ground surface visibility is very limited. In 1853, the storehouse (Structure $U$ ) was described as consisting of three rooms and an office constructed of $\log$ with dimensions of $24 \times 16$ feet. The blacksmith shop (Structure V) was described as constructed of adobe with dimensions of $14 \times 16$ feet.

The limited scope of this project did not allow time for subsurface testing in the vicinity of these two former structures. However, we felt confident that with the aid of a metal detector, the approximate location of the blacksmith shop could be relocated. Previous archaeological field work at other blacksmith shop sites has demonstrated that the subsurface soil will normally contain an unusually high proportion of metal-to-nonmetal artifacts. Sma11 pieces of iron, representing by-products and/or discards, are the most common artifacts.

A metal detector was used to survey an area roughly 10,000 feet square in the general area depicted on the 1853 sketch map for the two structures. A total of 51 electronic detection signals was registered and flagged with surveyor's flags. Almost half (24) of the detection signals were confined to an area about 40 × 40 feet in dimensions (Fig. 4). This area corresponds more closely to the blacksmith's shop than to the area depicted for the storehouse. The approximate locations of all detection signals were recorded on a sketch map for use in future investigations for this area. No artifacts were recovered from this general area.

\section{Survey Area 3 (Structure $K$ )}

The hospital was described in 1853 as 12 × 25 feet in dimensions and constructed of untreated logs that were "fast decaying" (Fig. 2). The location is depicted as north of structure G. This present-day area is vegetated by short grasses with no obvious surface indications to suggest a specific location for this former log structure. Intensive surface survey of the general area recovered a total of 44 historic and prehistoric artifacts (Table 3). Individual specimens were left in situ and flagged with surveyor's flags prior to recovery. The horizontal distribution of the artifacts (excluding prehistoric materials) roughiy corresponds to the area depicted for the hospital. There were no artifacts recovered that would 
suggest a strictly medical function (e.g., medicine bottles, glass syringe fragments). Additionally, several of the recovered ceramic sherds date to the last quarter of the 19th century. This area should be targeted for future field work.

\section{ARTIFACT ANALYSIS}

The CAR investigations at Fort Martin Scott recovered a total of 754 individual artifacts. Following field work, all materials were cleaned and catalogued. Specimens have been compared with those from other mid-19thcentury military sites (see Table 1). In general terms, the Fort Martin Scott assemblage contains few recognizably military artifacts by comparison to other forts. However, this is probably due to sampling bias.

Individual artifacts were sorted into several analytical groups for further analysis. These groups are based on the principal material used to construct the artifact (e.g., ceramics, iron, tin, glass). Table 3 provides the reader with a complete list of all artifacts and their provenience. The bulk of the dateable artifacts (i.e., ceramics, munitions) is considered to be contemporaneous with the U.S. Army occupation of Fort Martin Scott (1847-1853). Only a few of the ceramic artifacts (i.e., spongeware sherds; Fig. 15,k,m) appear to date to the Braeutigam family ownership of the property. A description of a few of the more noteworthy military artifacts follows.

\section{U.S. Military Button (Fig. 16,d)}

Provenience: Survey Area 1.

Description: A small U.S. Navy cuff button, $1.3 \mathrm{~cm}$ in diameter, two-piece brass with iron back, was recovered. It is made of iron which is heavily oxidized with a back mark that is illegible. It is convex with border and circle of ropes. It has 13 five-pointed stars encircling an eagle, facing left, perched on the stock of an upright anchor with fine lined background (similar to illustration NA 103, A7bert 1976). In 1830, naval regulations placed the eagle atop the stock of the upright anchor on officer's buttons, where it remained until 1852, when the eagle was moved to the shank of a horizontal anchor (A1bert 1976:86).

Percussion Caps (Fig. 16, 1, m)

Provenience: Survey Area 1 and Structure 0.

Description: Three copper "Top Hat" percussion caps, $0.7 \mathrm{~cm}$ high and $0.65 \mathrm{~cm}$ in diameter were recovered. Each cap has four small lips at the base, although two of the lips have been damaged on one specimen. All three examples appear to be unmarked as to maker, but are of the pattern most commonly seen on American specimens. Two specimens are shown (Fig. 16,1,m). The "Top Hat" pattern was generally for use on military muskets, and first appeared in Europe about the second decade of the 19th century (Gooding 1973:294) and generally went out of use by the late 1860s. 
Lead Bal1 (Fig. 16,0)

Provenience: Survey Area 1.

Description: A round lead bal1, $0.9 \mathrm{~cm}$ in diameter, slightly misshapen and flattened on one side from possible impact, was recovered. This corresponds to about a .36 caliber, which could have been used in a single-shot rifle or the 1851 model Colt's Navy Revolver.

Lead Bullet (Fig. 16,q)

Provenience: Survey Area 1.

Description: A conical lead bullet, $1.15 \mathrm{~cm}$ in diameter, and $1.9 \mathrm{~cm}$ in length was recovered. The bullet is badly distorted, with a $1.85-\mathrm{cm}$ gash along one side and a flanged base. There appears to be a single lubrication groove $0.6 \mathrm{~cm}$ above the base. The bullet is believed to have been fired as there is an impact mark near the nose and some traces of rifling. The size corresponds to a .44 caliber, and the style is identified as from a late model Colt dragoon revolver (McKee and Mason 1980:27), probably a model from the 1850 s.

Cartridge (Fig. 16,s)

Provenience: Survey Area 1.

Description: A fired brass cartridge casing centerfire, $5.15 \mathrm{~cm} 1$ ong, and $1.1 \mathrm{~cm}$ in diameter was recovered. Headstamp is marked "Peters/.30 Rems," and is of 20th-century manufacture.

Cartridge (Not Illustrated)

Provenience: Survey Area 1.

Description: A fired brass cartridge casing, rim fire, $2.95 \mathrm{~cm}$ 1ong, and $0.75 \mathrm{~cm}$ in diameter was recovered. Casing massed in the center. Headstamp of "U" from Rem'UMC cartridge company. Size is for .22 long rifle cartridge and dates from the 20th century.

\section{SUMMARY}

The CAR field investigations at Fort Martin Scott resulted in the identification and limited investigations of eight separate structures. Three additional areas, representing the former locations of the hospital, two enlisted barracks, and the blacksmith's shop and storehouse were intensively surveyed. Except for the guardhouse, all foundation remnants do not exceed ground level. Structures $E$ and $G$ still have fairly well-defined wall foundations; a11 other structures tested by this project are in a poor state of preservation. Including the guardhouse, 14 specific localities for structures depicted in the 1853 Freeman Inspection Map were investigated 
Figure 15. Ceramic Artifacts Recovered at Fort Martin Scott.

a-d, blue feather-edged decorated pearlware rim sherds, possibly manufactured by the Davenport Company;

e, blue transfer-printed pearlware body sherd;

$f$, flow-blue transfer-printed body sherd;

$g, h$, purple transfer-printed pearlware body sherds;

$i, j, \quad$ light blue banded slip pearlware body sherds;

$\mathrm{k}$, blue spongeware body sherd;

1, whiteware rimsherd with a single red band;

$\mathrm{m}$, blue spongeware body sherd;

$n-p$, banded slipware body sherds (black stripes on gold body);

$q$, banded slipware body sherd (light blue stripes on white body);

$r$, stoneware basal sherd (dark brown slip);

$s, t$, dark brown on white pearlware basal sherds. 
FORT MARTIN SCOTT / Artifact Analysis

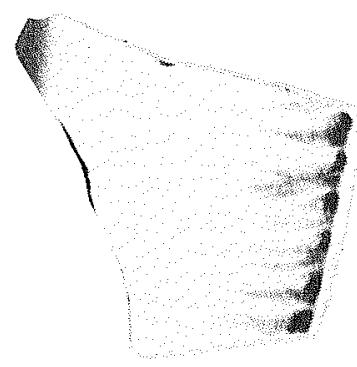

a

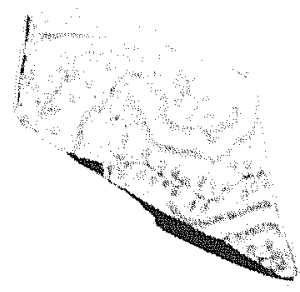

e

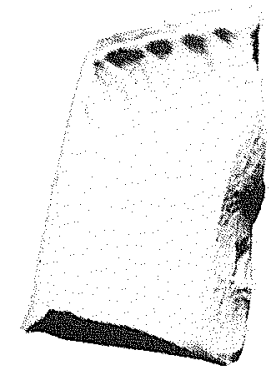

b

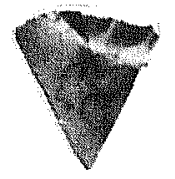

$f$

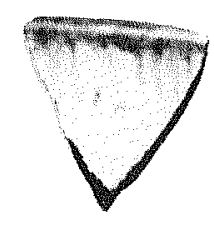

c

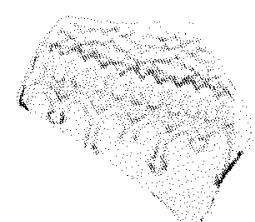

g

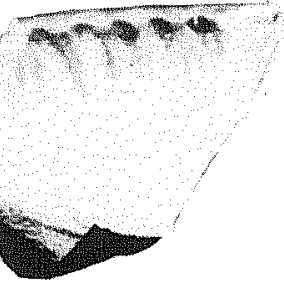

d

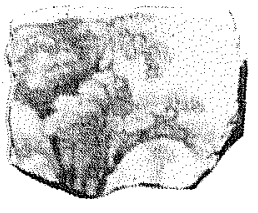

h
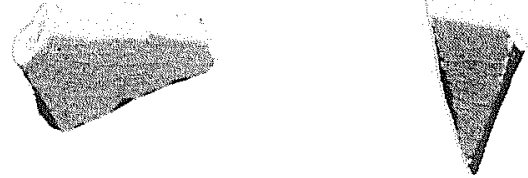

i

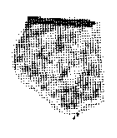

k

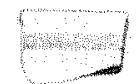

I

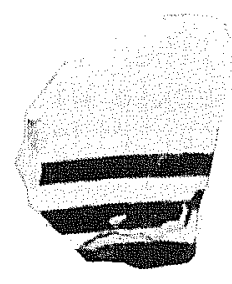

$p$
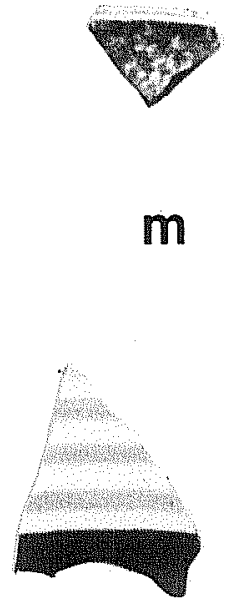

q

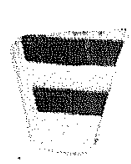

n

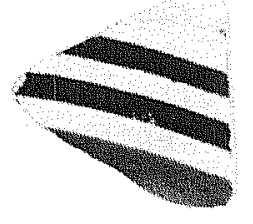

0

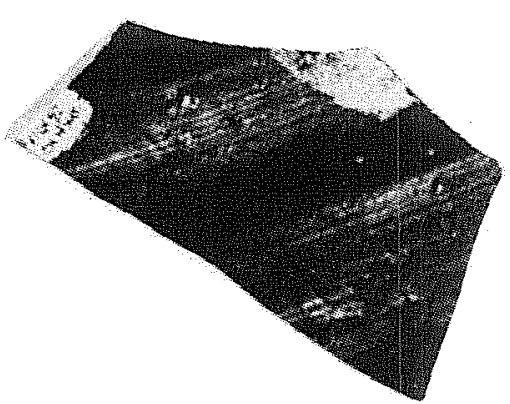

r
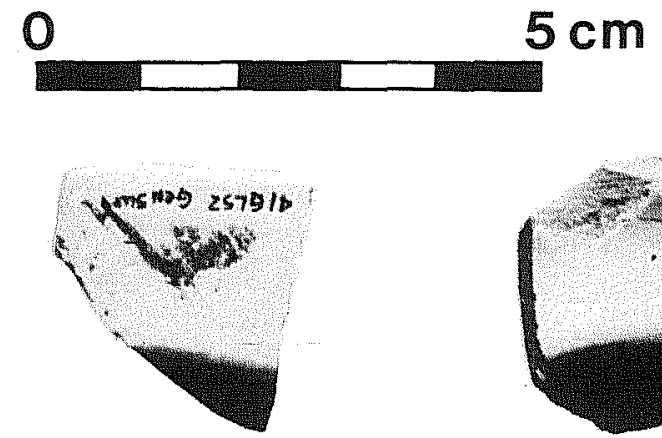

$\mathbf{S}$

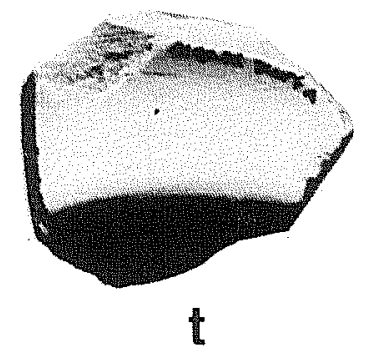


Figure 16. Artifacts Recovered at Fort Martin Scott.

a, four-hole shell button;

b, four-hole bone button;

c, four-hole cast lead button;

d, U.S. Navy button (1832-1852);

e, white clay pipe stem fragment;

$f-h$, brown ceramic pipe bowl fragments;

$i, j$, white clay pipe bowl fragments;

$k$, tan ceramic pipe bowl;

$1, \mathrm{~m}$, percussion caps (ca. 1850s);

$\mathrm{n}$, iron tongue from a buck $1 \mathrm{e}$;

o, .36 caliber lead ball (ca. 1850s);

$\mathrm{p}$, white milk glass button;

q, .44 caliber lead bullet (ca. 1850s);

$r$, iron buckle without tongue;

$s$, brass cartridge (20th century);

$t, u$, tin can fragments (1ate 19th century). 
FORT MARTIN SCOTT / Artifact Analysis

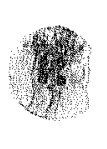

a

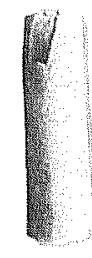

e

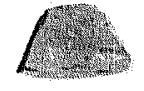

$f$
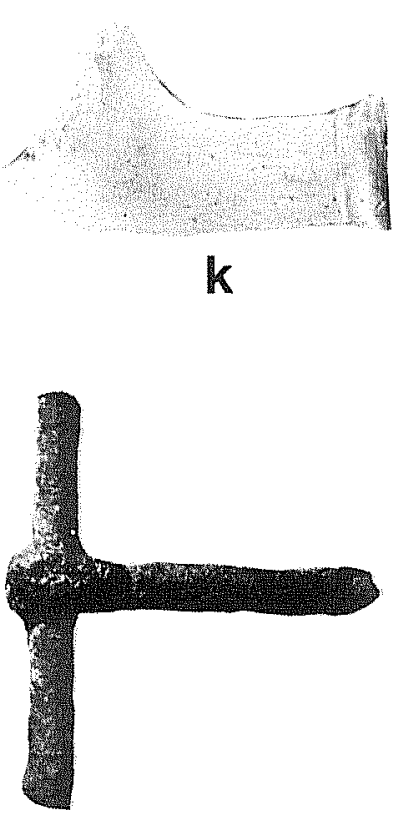

n

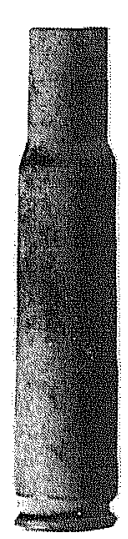

S

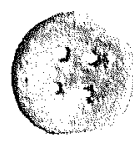

b

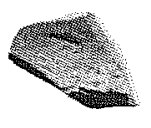

g

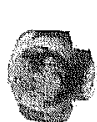

I

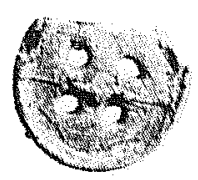

c

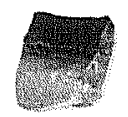

h

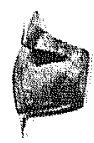

m

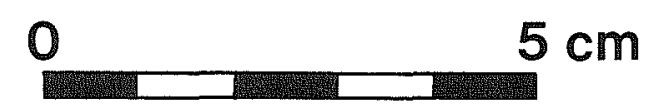

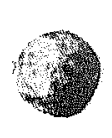

0

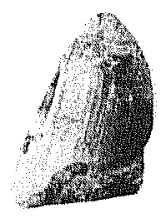

p

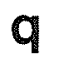

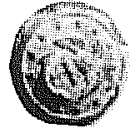

d

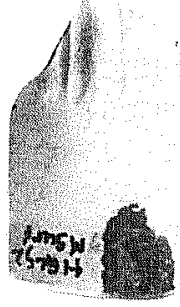

j
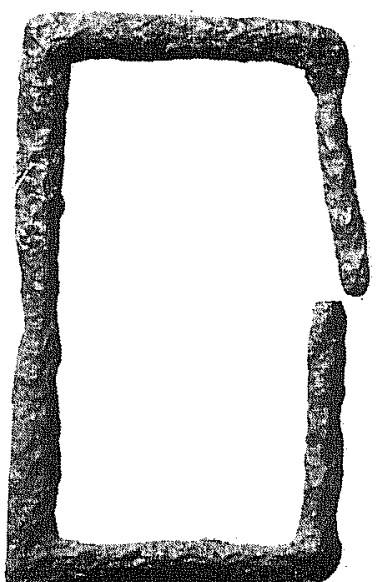

r

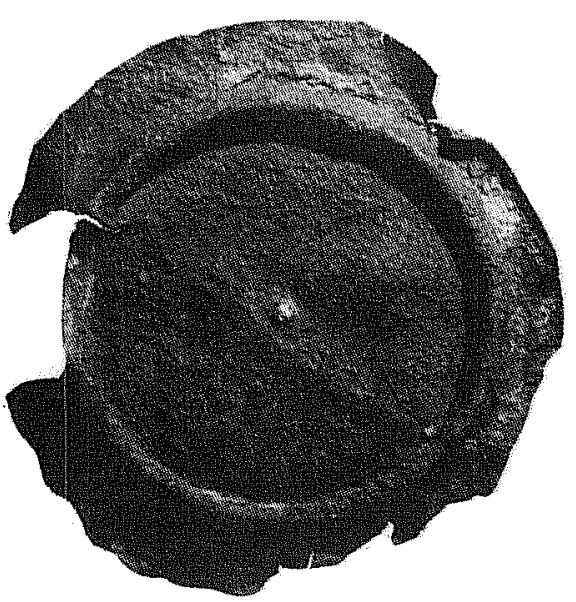

t

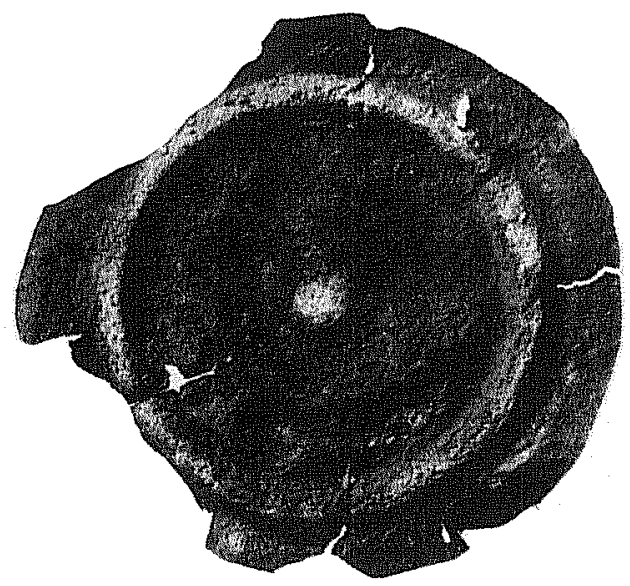

U 
during one week of field work (Fig. 2). Future field work should be able to establish the probable locations for the seven remaining structures reported to have existed at Fort Martin Scott in 1853.

The recovery of artifacts was fairly low, numbering 754 individual specimens. This was to be expected as field work concentrated on the identification of foundation remnants rather than the excavation of privies and suspected trash dumps. By far the most common artifacts found were hand-forged square-cut nails. A variety of glass fragments (green, black, brown, and clear) and several ceramic types (hand-painted whitewares, transfer-printed pearlwares, and banded slipwares; Fig. 15,a-j,1,s,t) were also recovered. Military artifacts were few; the items found are attributable to the original occupation of the fort.

Prehistoric and/or historic Indian occupation of the general site area is indicated by the presence of a few chipped stone artifacts. Historic records indicate that Penateka Comanche Indians frequented Fort Martin Scott. Future field work should specifically target suspected Indian campsites within the area currently leased to the Fredericksburg Heritage Federation.

The Fort Martin Scott project has provided preliminary findings on the extant portions of buildings that still exist at the site. This information is critical to the planned redevelopment of this site by the Fredericksburg Heritage Federation. This site has a great deal of archaeological potential for yielding significant new information on everyday life at a Texas frontier outpost. The entire site area (41 GL 52) should be nominated as a State Archeological Landmark.

\title{
RECOMMENDATIONS FOR FURTHER WORK
}

\author{
(Anne A. Fox)
}

Judging from the amount of information we were able to obtain about Fort Martin Scott in one week (see Table 4), it seems likely that it will be possible to determine the original locations of all the structures present on the site in 1853. The various methods used to locate building foundations should be concentrated toward this result, both from the standpoint of interpretation of the site to the public and in order to be certain that the current lease boundaries contain the entire fort complex.

In the near future, we recommend that a complete, detailed history be composed of the fort and its relationships with elements of the local community. This might include a trip to the National Archives where a personal search could be made for additional information on the fort and on the persons who served there. It should also include detailed study of Indian-related documents which might throw more light on the fort's role in Indian trade and peace-making operations. Such a history would serve as the basis for interpretive exhibits when the site is opened to the public. For an idea of how such information can be used, we recommend a visit to fort sites administered by the Texas Parks and Wildlife Department, such as Fort McKavett and Fort Lancaster. 
TABLE 4. LISTING OF STRUCTURES AND STRUCTURAL LOCALITIES INVESTIGATED BY THIS PROJECT

\begin{tabular}{|c|c|c|c|c|c|}
\hline $\begin{array}{l}1853 \text { Map } \\
\text { Reference }\end{array}$ & Function & $\begin{array}{l}\text { Artifacts } \\
\text { Recovered }\end{array}$ & $\begin{array}{l}\text { Percent of } \\
\text { Foundation } \\
\text { Located }\end{array}$ & $\begin{array}{l}\text { Current } \\
\text { Recommendations }\end{array}$ & $\begin{array}{l}\text { Potential for Ground } \\
\text { Level Reconstruction }\end{array}$ \\
\hline Structure A & $\begin{array}{l}\text { Commander's } \\
\text { Residence }\end{array}$ & 199 & 5 & $\begin{array}{l}\text { Stabilize and rebury } \\
\text { extant portions }\end{array}$ & Poor \\
\hline Structure B & $\begin{array}{l}\text { Officers's } \\
\text { Residence }\end{array}$ & 75 & 5 & $\begin{array}{l}\text { Stabilize and rebury } \\
\text { extant portions }\end{array}$ & Poor \\
\hline Structure $E$ & $\begin{array}{l}\text { Officer's } \\
\text { Residence }\end{array}$ & 30 & 75 & $\begin{array}{l}\text { Stabilize and rebury } \\
\text { extant portions }\end{array}$ & Excellent \\
\hline Structure G & $\begin{array}{l}\text { Officer's } \\
\text { Residence }\end{array}$ & 23 & 60 & $\begin{array}{l}\text { Stabilize and rebury } \\
\text { extant portions }\end{array}$ & Excellent \\
\hline Structure $\mathrm{J}$ & $\begin{array}{l}\text { Sutier } \\
\text { Store }\end{array}$ & 0 & $5(?)$ & $\begin{array}{l}\text { Stabilize and rebury } \\
\text { extant portions }\end{array}$ & Fair \\
\hline $\begin{array}{l}\text { Structure K } \\
\text { (Survey Area 3) }\end{array}$ & Hospital & 44 & 0 & $\begin{array}{l}\text { Additional field } \\
\text { investigation }\end{array}$ & Poor \\
\hline Structure L & Laundry & 0 & $5(?)$ & $\begin{array}{l}\text { Additional field } \\
\text { investigation }\end{array}$ & Fair \\
\hline Structure M & Bake House & 28 & (bake oven) & $\begin{array}{l}\text { Stabilize and rebury } \\
\text { extant portions }\end{array}$ & Excellent \\
\hline Structure N & $\begin{array}{l}\text { Guardhouse and } \\
\text { Braeutigam } \\
\text { Homestead }\end{array}$ & 0 & 100 & Complete restoration & Excellent \\
\hline Structure 0 & $\begin{array}{l}\text { Enlisted } \\
\text { Barracks }\end{array}$ & 126 & 15 & $\begin{array}{l}\text { Stabilize and rebury } \\
\text { extant portions }\end{array}$ & Fair \\
\hline
\end{tabular}


It would be well to capitalize on the differences between Fort Martin Scott and other Texas forts of the same period, particularly the opportunity to interpret U.S. Army-Indian relations. The possibility of finding Indian campsites in the vicinity of the fort should be explored. The surprising variety of types of construction at this fort should also be described and demonstrated through exhibits.

Future archaeological investigations, in addition to locating the rest of the structures, should focus on the study of individual areas that will yield more specific information on life at the fort. This should include the back yards of several officers' quarters and the areas immediately relating to the enlisted men's barracks. Such work at Fort Griffin (Fox 1973) produced excellent results in the way of artifacts and information on locations of outbuildings, privies, etc.

Since there is some difference between the 1853 description of Structure $G$ and what was found through our investigation, it might be useful to do a complete excavation of this foundation. This investigation would probably allow confirmation of the actual date of construction and possible later uses of the building after the fort was decommissioned.

We would emphasize that, although we will probably be able to reconstruct the outline or "footprint" in the ground of most of the buildings, little if any information exists on what they looked like above ground. For this reason, we suggest that any restoration efforts be limited to stabilization, or perhaps reconstruction of at least some of the building foundations to just above the ground level. Through careful investigations and measured drawings, it might be possible to tell whether the Eckhardt log house did come from the fort site. If it can be so established beyond a reasonable doubt, a replica of the log house could legitimately be constructed on the property. Otherwise, we recommend that the concentration on an above ground structure be on the restoration of the Guardhouse to its original appearance.

\section{REFERENCES CITED}

Albert, A. H.

1976 Record of American Uniform and Historical Buttons. Bicentennial Edition. Boyertown Publishing Company, Boyertown, Pennsylvania.

Bel1, Klein, and Hoffman

1980 Fort Concho National Historic Landmark: A Masterplan for Development. Report by Be11, Klein, and Hoffman, Architects and Restoration Consultants, Inc., San Ange7o.

Biesele, R. L.

1930 History of the German Settlements, 1831-1861. Von Boeckmann-Jones, Austin. 
Black, A. and J. D. Ing

1980 Fort McKavett State Historic Site, Menard County, Texas, Archeological Investigations, 1974-1977. Texas Parks and Wildlife Department, Historic Sites and Restoration Branch, Austin.

Brown, W. E.

1965 Master Plan for Fort Lancaster Historical Park, Crockett County, Texas. Mimeograph report on file at State Building Commission, Austin.

Carter, E. S.

1974 Fort Mckavett-Menard County, Texas: Archeological and Architectural Details of the Bakery, Barracks, and Headquarters Building, Spring 1973. Texas Archeological Survey, The University of Texas at Austin, Research Report 20.

Clark, J. W., Jr.

1972 Archeological Investigations at Fort Lancaster State Historic Site, Crockett County, Texas. Texas Archeological Salvage Project, The University of Texas at Austin, Research Report 12 .

Clarke, 0. D.

1935 Fort Griffin. Albany Chamber of Commerce. Albany, Texas.

Council of Texas Archeologists (CTA)

1981 Guidelines for Cultural Resource Management Reports. Council of Texas Archeologists, Newsletter 5(2).

Crimmins, M. L., editor

1939 Fort McKavett, Texas. The Southwestern Historical Quarterly $42: 351-387$.

1947a W. G. Freeman's Report on the Eighth Military Department. The Southwestern Historical Quarterly 51(1):54-58.

1947b W. G. Freeman's Report on the Eighth Military Department. The Southwestern Historical Quarterly 51(2):167-174.

1948 W. G. Freeman's Report on the Eighth Military Department. The Southwestern Historical Quarterly 51(3):252-258.

1949 W. G. Freeman's Report on the Eighth Military Department. The Southwestern Historical Quarterly 53(1):202-208. 
Eastman, S.

1961 A Seth Eastman Sketchbook, 1848-1849. Introduction by Lois Burkhalter. University of Texas Press, Austin.

Fletcher, H. T.

1932 01d Fort Lancaster. West Texas Historic and Scientific Quarterly 42:251-257.

Fox, A. A.

1973 Archeological Investigations at Fort Griffin State Historic Park, Texas, February, 1973. Texas Archeological Survey, The University of Texas at Austin, Research Report 21.

1975 Archeological Investigations at Fort Griffin Part 2. Office of Archeology and Historic Preservation, National Park Service, Archeological Completion Report, Series 10. Department of the Interior, Washington, D.C.

1976 Archaeological Investigations at Fort Griffin State Historic Park, Shackelford County, Texas. Center for Archaeological Research, The University of Texas at San Antonio, Archaeological Survey Report 23.

Fox, D. E.

1978a Archaeological Monitoring and Testing for Building Construction and Landscaping on the Site of Ft. McIntosh, Laredo, Texas. Letter report from the Center for Archaeological Research, The University of Texas at San Antonio, to Laredo Junior College.

1978b Archaeological Testing for Construction of an Office Building on the Site of Ft. McIntosh, Laredo, Texas. Letter report from the Center for Archaeological Research, The University of Texas at San Antonio, to Laredo Junior College.

1979 Archaeological Testing at Fort McIntosh, Laredo Junior College Campus, Laredo, Texas. Center for Archaeological Research, The University of Texas at San Antonio, Archaeological Survey Report 68.

Fredericksburg Chamber of Commerce

n.d. Fort Martin Scott (1847-1852): A Brief History and Collection of Historical Documents with Typewritten Transcripts. The Fredericksburg Chamber of Commerce.

Fredericksburg Standard

1955 Interview with Mrs. Henry W. Braeutigam, November 16. 
Freeman, W. G.

1853 Rough Plan of Fort Martin Scott. National Archives, Washington, D. C.

Gi17espie County, Texas

Gillespie County Deed Records

Vo1. E. Gi1lespie County Courthouse, Fredericksburg, Texas

Gooding, S. J.

1973 The Development of Percussion Primers. Arms and Armor Annual 1:283-297. Robert Held, editor.

Graham, R. E.

1968 Texas Historic Forts, Part IV, Griffin. One of a series of reports submitted by the School of Architecture, The University of Texas at Austin, to the Texas Parks and Wildlife Department, Austin.

Green, F. E.

1969 Report on Preliminary Archaeological Investigations at Ft. McKavett, Texas. Texas Tech University, Lubbock.

Hays, T. R. and E. B. Jelks

1966 Archeological Exploration at Fort Lancaster, 1966: A Preliminary Report. State Building Commission, Archeological Program, Report 4. Austin.

Hester, T. R., R. F. Heizer, and J. A. Graham

1975 Field Methods in Archaeology. 6th edition. Mayfield Publishing Co., Palo Alto, California.

Ing, J. D. and G. Kegley

1971 Archeological Investigations at Fort Leaton Historic Site, Presidio County, Texas, Spring 1971. Texas Parks and Wild1 ife Department, Austin.

Ivey, J. E., T. Medlin, and J. D. Eaton

1977 An Initial Archaeological Assessment of Areas Proposed for Modification at Fort McIntosh, Webb County, Texas. Center for Archaeological Research, The University of Texas at San Antonio, Archaeological Survey Report 32. 
King, I. M.

1967 John 0. Meusebach, German Colonizer in Texas. University of Texas Press, Austin.

Maxwe11, R. A.

1940 Fort Griffin State Park: A Discussion of the General Geology and Ground Water Resources. Unpublished report prepared for the Texas State Parks Board and the U.S. Department of the Interior, National Park Service.

McGuire, T. C.

ms. A Model of Fort Ewell Constructed Under the Gilmore Method of Historic Site Identification. Manuscript on file at the Center for Archaeological Research, The University of Texas at San Antonio.

Mckee, W. R. and M. E. Mason

1980 Civil War Projectiles II: Small Arms and Field Artillery, with supplement. Moss Publications, Orange, Virginia.

Medlin, T.

1977a Archaeological Testing for Proposed Water/Sewer Line Ditch at Fort McIntosh, Laredo, Texas. Letter report from the Center for Archaeological Research, The University of Texas at San Antonio, to Laredo Junior College.

1977b A Preliminary Report on Archaeological Testing at Fort McIntosh, Laredo Junior College Campus, Laredo, Texas. Letter report from the Center for Archaeological Research, The University of Texas at San Antonio, to Laredo Junior College.

Mueller, 0 .

1935 Texas: With Particular Reference to German Immigration and the Physical Appearance of the Country. Written in German by Ferdinand Roemer, translated by 0swald Mueller. Standard Printing Co., San Antonio.

National Archives

1849 Order No. 84. 8th Military Department, dated December 8, 1849. Washington, D.C.

1853 Special Order No. 95. 8th Military Department, dated December 29, 1853. Washington, D.C. 
Nelson, G.

1981 Preliminary Archaeological Survey and Testing of Fort Inge, Texas. Uvalde County Historical Commission, Uvalde, Texas.

1982 Additional Archaeological Survey and Testing at Fort Inge. Uvalde County Historical Commission, Uvalde, Texas.

Newcomb, W. W., Jr.

1961 The Indians of Texas: From Prehistoric to Modern Times. University of Texas Press, Austin.

01ds, D. L.

1969 Archeological Investigations at Fort Griffin Military Post, Shackelford County, Texas. Texas Archeological Research Laboratory, The University of Texas at Austin.

$01 \operatorname{sen}$, S. C.

1975 Fort Richardson. Office of Archeology and Historic Preservation, National Park Service, Archeological Completion Report, Series 6. Department of the Interior, Washington, D.C.

Penniger, R.

1971 Fredericksburg, Texas: The First Fifty Years. Translated by Dr. Charles L. Wisseman, Sr. Fredericksburg Publishing Co., Fredericksburg.

Prewitt, E. R.

1979 National Register of Historic Places Nomination Form. Prepared by E. Prewitt, dated May 2, 1979.

Rickey, D., Jr. and C. S. Pope

1966 Fort McKavett Texas, A Special Report on Potential for Park Development. United States Department of the Interior, National Park Service, Washington, D.C.

Rister, C. C.

1956 Fort Griffin on the Texas Frontier. University of Ok1ahoma Press, Norman. 
Sauer, A. B.

n.d. A History of Johann Wolfgang Braeutigam and Wife Christine Kensing Braeutigam. Compiled and issued by ATice Braeutigam Sauer and the descendants of the third and fourth generations. Privately printed, Fredericksburg, Texas.

Taniguchi, A. Y., R. E. Graham, and G. C. Hamblett

1968a Texas Historic Forts, Part II, Fort McKavett. One of a series of reports submitted by the School of Architecture, The University of Texas at Austin, to the Texas Parks and Wildlife Department, Austin.

1968b Texas Historic Forts, Part III, Fort Lancaster. One of a series of reports submitted by the School of Architecture, The University of Texas at Austin, to the Texas Parks and Wildlife Department, Austin.

Wagner and Klein, Inc.

1983 Preservation Plan for Fort Martin Scott, Fredericksburg, Texas. Prepared by Wagner and Klein, Inc. Architectural Planning and Historic Preservation Programming, Fredericksburg, Texas.

Yates, C.

1975 Archeological Investigation at Fort Griffin. Office of Archeology and Historic Preservation, National Park Service, Archeological Completion Report, Series 3. Department of the Interior, Washington, D.C. 


\section{APPENDIX I}

\section{ESTIMATES OF MATERIALS AND LABOR REQUIRED TO COMPLETE THE POST OF FORT MARTIN SCOTT}

The text for Appendix I is taken from a copy of the original handwritten document supplied to this project by Tyrus Cox of Fredericksburg.

No. 1: Officers Quarters: 1 Building of 4 Rooms Commenced.

\section{Materials}

\begin{tabular}{|c|c|c|}
\hline $\begin{array}{l}\text { Adobes } \\
\text { Lumber } \\
\text { Shingles } \\
\text { Lime } \\
\text { Mortice Locks } \\
\text { Smal1 Spring bolts } \\
\text { Moveable Butts } \\
\text { Screws, assorted } \\
\text { Nails } \\
\text { Glass }\end{array}$ & 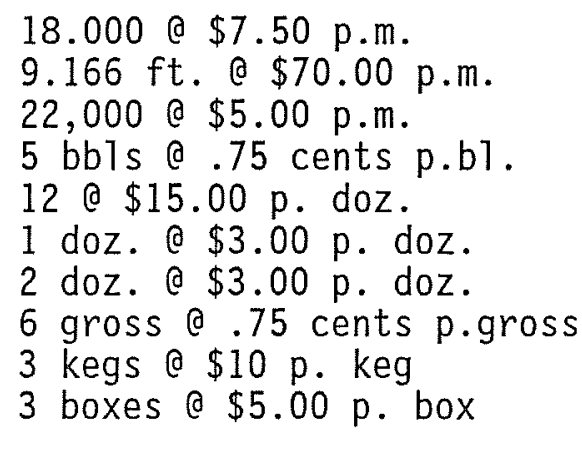 & $\begin{array}{r}\$ 135.00 \\
641.62 \\
110.00 \\
56.25 \\
15.00 \\
3.00 \\
6.00 \\
4.50 \\
30.00 \\
15.00 \\
\$ 1016.37\end{array}$ \\
\hline
\end{tabular}

Labor

1 Master Workman 1 month @ $\$ 75.00$

75.00

20 Mechanics

1 month @ $\$ 45.00$

900.00

$\$ \underline{975.00}$

Required to complete No. $1 \$ 1991.37$

No. 2 Guard House Commenced.

\section{Materials}

Lumber

Lime

Shingles

Nails

Locks
$4,068 \mathrm{ft} @ \$ 70.00$ p.m.

$30 \mathrm{bbls} @ .75$ cents

18000 e $\$ 5.00 \mathrm{p} . \mathrm{m}$.

2 kegs a $\$ 10.00 \mathrm{p}$. keg

6 @ $\$ 18.00$ p. doz.
$\$ 284.76$

22.50

90.00

20.00

$\$ 42 \frac{9.00}{6.26}$

Labor

1 Master Workman for 7 days $\$ \$ 75.00$ per month 20 Mechanics for 7 days $\$ 45.00$ per month

$\$ 17.50$

210.00

$\$ \frac{210.00}{227.50}$

Required to complete No. $2 \$ 653.76$ 
No. 3 Band Quarters (nearly completed)

\section{Materials}

Lumber

$2.100 \mathrm{ft}$. @ $\$ 70.00$ per m.

$\$ 147.00$

Nails

$1 \mathrm{keg} 0 \$ 10 \mathrm{p}$. keg

10.00

? Locks

3 @ $\$ 1.25$ each

3.75

? Bolts

1 doz. o $\$ 3.00 \mathrm{p} \mathrm{doz}$.

3.00

Strap Hinges (pair of) 15 @ $\$ 1.00 \mathrm{p}$. pair

Labor

1 Master Workman for 3 days $\$ \$ 75.00$ per month

$\$ 7.50$

20 Mechanics for 3 days a $\$ 45.00$ per month

Required to complete No. $3 \$ \$ 276.25$

No. 4 Hospital (not commenced)

\section{Materials}

Adobes

Lumber

Shingles

Lime

Locks

Bolts

Butts

Screws (ass)

Nails

Glass
20.000 o $\$ 7.50$ p.m.

$12.000 \mathrm{ft}$. $\$ 70.00 \mathrm{p} . \mathrm{m}$.

25.000 e $\$ 5.00$ p.m.

100 bbls. .75 cents

1 doz. @ $\$ 15.00$ p.doz.

1 doz. \$ $\$ 3.00$ p. doz.

2 doz. a $\$ 3.00$ p. doz.

6 gross $@ .75$ cents $p$. gross

3 kegs $0 \$ 10.00$ per keg

3 boxes a $\$ 5.50 \mathrm{p}$. box
$\$ 150.00$

840.00

125.00

75.00

15.00

3.00

6.00

4.50

30.00

16.50

$\$ 1265.00$

Labor

1 Master Workman for 1 month $0 \$ 75.00$ per month

20 Mechanics 1 month a $\$ 45.00$ per month (each)

$\$ 75.00$

900.00

$\$ 975.00$

$\$ 2240.00$

Total to Build No. 4

No. 5 Magazine (not commenced)

Material

Lumber

Lime

Lock, bolts, \& Hinges

$\mathrm{Nails}$ 
Labor

1 Master Workman 5 days a $\$ 75.00$ per month

20 Mechanics for 5 days a $\$ 45.00$ per month (each)

Total to build Magazine

$\$ 12.50$

150.00

$\$ 162.50$

$\$ 660.00$

Total amount required to complete the Post $\$ 5822.88$

(Signature)

(Approved)

*T.Staniford

Lt. Cot. 8 Infantry

*Thomas Staniford, Brt. Col. Co?.

8th Infantry-took command of Fort Martin Scott Dec. 22, 1849. 


\section{APPENDIX II}

\section{LIST OF THE U.S. ARMY FORTS CONSTRUCTED IN TEXAS FOLLOWING STATEHOOD IN 1845}

This information was originally printed in Fort Martin Scott (1847-1852): A Brief History and Collection of Historical Documents with Typewritten Transcripts (Fredericksburg Chamber of Commerce n.d.).

$\begin{array}{llc}\text { Name of Fort } & \text { Location } & \text { Year Established } \\ \text { Marcy } & \text { Corpus Christi } & 1845 \\ \text { Brown } & \text { Brownsville } & 1846 \\ \text { Ringgold } & \text { Rio Grande City } & 1846 \\ \text { Inge } & \text { Uvalde } & 1846 \\ \text { Martin Scott } & \text { Fredericksburg } & 1848 \\ \text { Gates } & \text { Gatesville } & 1849 \\ \text { Worth } & \text { Fort Worth } & 1849 \\ \text { Graham } & \text { Hillsboro } & 1849 \\ \text { Groghan } & \text { Burnet County } & 1849 \\ \text { Lincoln } & \text { Medina County } & 1849 \\ \text { B1iss } & \text { El Paso } & 1849 \\ \text { Merri11 } & \text { Live Oak County } & 1850 \\ \text { McIntosh } & \text { Laredo } & 1850 \\ \text { Phantom Hi11 } & \text { Abilene } & 1851 \\ \text { Drum } & \text { Zapata County } & 1851 \\ \text { Mason } & \text { Mason } & 1851 \\ \text { Be1knap } & \text { Young County (West of Graham) } & 1851 \\ \text { Chadbourne } & \text { Coke County } & 1852 \\ \text { McKavett } & \text { Menard Conty (West of Junction) } & 1852 \\ \text { Terrett } & \text { Kimble County } & 1852 \\ \text { Ewel1 } & \text { La Salle County } & 1852 \\ \text { Clark } & \text { Brackettville } & 1854 \\ \text { Davis } & \text { Jeff Davis County } & 1854 \\ \text { Quitman } & \text { Rio Grande (Hudspeth County) } \\ \text { Lancaster } & \text { Crockett County } & 1855 \\ \text { Hudson } & \text { Val Verde } & 1857 \\ \text { Stockton } & \text { Pecos County } & 1859\end{array}$

After the Civil War, many of the above forts were reorganized or reopened and the following new forts were added.

Concho

Griffin

Richardson

Elliott

Hancock
San Ange10

Shackel ford County

Jacksboro

Mobeetie (Wheeler County)

Rio Grande (Hudspeth County)
1867

1867

1867

1875

$\cdot 1882$ 


\section{APPENDIX III}

\section{U.S. ARMY RESIDENTS AT FORT MARTIN SCOTT ACCORDING TO THE FEDERAL CENSUS OF 1850}

This information was collected by Henry K. Judd, assistant Marshall for the U.S. Census on September 18, 1850. (Transcribed copy provided by Tyrus Cox of Fredericksburg.)

\section{Name}

Thos. Staniford, Lieut. Colonel

H. W. Merri11, Major

J. Beardsley, Captain

E. D. Blake, Lieutenant Henry L. Ha11, Sergeant John R. Scott, Sergeant John F. Smith, Sergeant John Black, Sergeant Richard Bangs, Corporal Daniel Hart, Corporal W. W. Davis, Corporal Michael Donald, Corporal

$\begin{array}{rcc}\text { Age } & \text { Sex } & \text { Occupation } \\ & & \\ 55 & \text { M } & \text { Soldier } \\ 35 & \text { M } & \text { Soldier } \\ 30 & \text { M } & \text { Soldier } \\ 26 & \text { M } & \text { Soldier } \\ 28 & \text { M } & \text { Soldier } \\ 29 & \text { M } & \text { Soldier } \\ 26 & \text { M } & \text { Soldier } \\ 26 & \text { M } & \text { Soldier } \\ 30 & \text { M } & \text { Soldier } \\ 26 & \text { M } & \text { Soldier } \\ 24 & \text { M } & \text { Soldier } \\ 25 & \text { M } & \text { Soldier }\end{array}$

Birthplace

Connecticut

New York

New York

South Carolina Connecticut Pennsylvania Maryland Ire 1 and Ireland New York Kentucky New York 


\section{APPENDIX IV}

\section{TEXT OF THE 1853 FREEMAN INSPECTION REPORT FROM FORT MARTIN SCOTT}

The text for Appendix IV is excerpted from W. G. Freeman's report on the Eighth Military Department, edited by M. L. Crimmins (1949), which appeared in The Southwestern Historical Quarterly 53(1):202-208.

From Fort Inge it was neccessary to return to San Antonio to refit, preparatory to commencing the tour of the Northern posts of the department. The distance, 86 miles E.N.E., is three days travel over streams are crossed on the route, which passes by Fort Lincoln, now abandoned. Of these the principal are the Frio, Sabinal, Seco, Hondo, Medina, and Leon, distant, in the order named, 7, 20, 33, 47, 61 , and 79 miles, from Fort Inge. Farm houses begin to appear after crossing the Seco, near which there is a small German settlement, called Dhanis. Twelve miles beyond is the Hondo, and between this and Castroville, on the Medina, many extensive fields of corn were passed. Castroville is a thriving place of some 800 inhabitants; and within the circuit of a few miles there is probably, an equal population. The picturesque beauty that is rarely excelled in any country; in the fertility of its soil, it cannot be surpassed.

I left San Antonio August 11th to inspect the northern chain of posts, and reached Fort Martin Scott, distant 65 miles, a few degrees to the west of North, August 13th. The intermediate country is finely watered and very diversified in appearance, much of the route being over bald mountainous ridges. The Cibolo was crossed at 31 miles, and the Guadalupe at 46 miles from San Antonio. This last is a clear, swift stream, with steep banks, and was about 60 feet wide and two feet deep at the fork; but it is often swollen as to be impassable.

XVI.-Fort Martin Scott-(Inspected August 13, 1853.)

This post is on a small stream called Barron's Creek, which empties into the Pedernales, a branch of the Colorado. Two miles West is Fredericksburg, a German settlement of between 800 and 900 inhabitants, and where there is a post office. The mail comes weekly by Austin, and there is also a weekly express communication with San Antonio. The buildings put up are of a better description than at most of the posts in Texas. The site belongs to Mr. Twohig of San Antonio. It is believed no rent is paid for the land, but the owner has received a considerable sum for fuel and timber cut, and the improvements will belong to him when the troops are withdrawn.

This station is now kept up as a forage depot for trains supplying the upper posts. The garrison consists of a Sergeant, a Corporal and 16 men of the 8th Infantry, under Lt. Theodore Fink of that regiment who has been in command since october 1, 1852. A sergeant and five men of the detachment are on extra duty; the remainder serve as a guard. The men are variously equipped. Some with the ordinary percussion musket and others with the Maynard primer 
musket, black belts and white belts are intermixed; some are destitute of parts of their equipment; one was without arms; and almost a11 had a very limited supply of clothing. They have not received much instruction and made but an indifferent appearance on parade. The quarters were in good order and due attention seemed to be paid to the preservation of the other public buildings.

An Ordnance Sergeant is stationed here but there is little for him to do, the only Ordnance at the post being a $12 \mathrm{pd}^{\prime} r$. mountain howitzer, with less than 100 rounds of fixed ammunition and 33 pounds of powder.

\section{Quartermaster's Department}

No citizens are employed and no purchases are made except of forage and small quantities of charcoal for the smithery. There are 900 bushels of corn and 50 tons of hay on hand. The corn was procured at 50 cents per bushel, the hay at $\$ 4.90$ per ton. There is a considerable quantity (21,000 feet) of lumber lying in store, which might be used at the more advanced frontier posts with much advantage to the comfort of the troops. Lt. Fink's accounts were in order and had all been seasonably rendered.

\section{Subsistence Department}

Provisions are obtained from the San Antonio depot. Some 3,000 rations were on hand and they were in good condition. The cost of the ration delivered at the post is $171 / 2$ cents. No parts of it could be bought on advantageous terms in the vicinity. On account of the smallness of the command, fresh beef cannot be obtained. It is sold generally at 5 cents per pound.

\section{Medical Department}

Neither an Asst. Surgeon nor a Hospital Steward is attached to the command, but there is a considerable quantity of hospital stores at the post. These were brought from Fort Gates when that post was broken up. They are not required here and should be sent elsewhere. Lt. Fink informs me he requested instructions many months since from the then chief Quartermaster (Lt. Col. Tompkins) in regard to disposing of them, but had received no orders on the subject.

There seems to me little advantage in continuing to occupy Fort Martin Scott, and I think the discipline of the service would be promoted by sending the detachment to its regiment. Forage for passing trains might be purchased from dealers in Fredericksburg, at rates fixed by the Quartermaster's Department, as is now done at Castroville, and the necessity of detaching men more than 100 miles from their companies as a guard to a small forage depot, would be thereby obviated. 
